\title{
Universiteit
}

Leiden

The Netherlands

\section{The Secular Outlook: In Defense of Moral and Political Secularism}

Cliteur, P.B.

\section{Citation}

Cliteur, P. B. (2010). The Secular Outlook: In Defense of Moral and Political Secularism. Chichester: Wiley-Blackwell.

doi:10.1002/9781444325324

Version:

Not Applicable (or Unknown)

License:

Leiden University Non-exclusive license

Downloaded from: $\quad$ https://hdl.handle.net/1887/16692

Note: To cite this publication please use the final published version (if applicable). 


\section{1}

\section{Atheism, Agnosticism, and Theism}

Non-Religious Ethics is at a very early stage. We cannot yet predict whether, as in Mathematics, we will all reach agreement. Since we cannot know how Ethics will develop, it is not irrational to have high hopes. (Derek Parfit, 1984) ${ }^{1}$

He has told you, O man, what is good; and what does the Lord require of you but to do justice, and to love kindness, and to walk humbly with your God? (Micah 6:8)

Let us start with what people most often associate with "the secular outlook." If with anything at all, they associate it with atheism. But what is atheism? Sometimes atheism is presented as a coherent worldview, encompassing all the other traditions supposedly associated with the secular outlook. On this basis the Christian theologian and physicist Alister McGrath (1953- ) writes: "Atheism is the religion of the autonomous and rational human being, who believes that reason is able to uncover and express the deepest truths of the universe, from the mechanics of the rising sun to the nature and final destiny of humanity." ${ }^{2}$ The first thing that strikes us is that atheism is presented here as a "religion." A second point that is remarkable is that McGrath depicts as "atheism" beliefs that most people would associate with "rationalism." In clarifying his definition the author even introduces other elements, such as optimism. Atheism, so McGrath writes, "was a powerful, self-confident, and aggressive worldview. Possessed of a boundless confidence, it proclaimed that the world could be fully

1 Parfit, Derek, Reasons and Persons, Clarendon Press, Oxford 1984, p. 454.

2 McGrath, Alister E., The Twilight of Atheism: The Rise and Fall of Disbelief in the Modern World, Doubleday, New York 2004, p. 220. 
understood and subsequently mastered." ${ }^{3}$ Often these definitions seem animated by an aversion to the denial of God. This also seems true in the case of McGrath. McGrath wrote a history of atheism based on a claim that its significance was declining.

A similar thesis is defended by the prolific Catholic historian Paul Johnson (1928- ). "Atheism as a positive set of beliefs, including a code of moral behavior, has failed to flourish," Johnson writes. ${ }^{4}$ It may be that fewer and fewer people in Western countries practice religion, Johnson tells us, but the number of those prepared to state their disbelief in God openly and specifically is extremely small. There is only a small minority that does that, whose numbers are probably no greater today than in the time of Percy Bysshe Shelley (1792-1822), who was expelled from Oxford University for his atheism. Shelley's Queen Mab: A Philosophical Poem (1813) was a forceful attack on organized religion. It takes the form of a dream-vision allegory in which the fairy Queen Mab takes the mortal maiden Ianthe on an extraterrestrial excursion in order to show her the past, present, and future states of the human world. According to Shelley, the past is irrational. It is the record of one mistake after another. The present is irreversibly corrupted by kings, priests, and statesmen. But the future will be a supremely glorious affair. ${ }^{5}$ Several atheistic passages were removed from the first edition, but they were restored in the second. The poem's publisher, Edward Moxon (1801-1858), was prosecuted and convicted of blasphemous libel. In the 1820s the British intellectual and bookseller Richard Carlile (1790-1843) issued a new edition of the poem.

That the development of atheism is still at the same stage as Shelley left it at the beginning of the nineteenth century, as Paul Johnson contended in 1996, is not very convincing given the vast quantity of literature that has appeared on atheism recently. But maybe this has to do with the fact that it is far from clear what Johnson means when he uses the term "atheism."

More attention is given to this matter in monographs explicitly devoted to the subject. According to Julian Baggini (1968-) atheism is "extremely simple to define," because "it is the belief that there is no God or gods."

In other definitions atheism is contrasted with theism. Robin Le Poidevin (1962- ) writes: "An atheist is one who denies the existence of a personal, transcendent creator of the universe rather than one who simply lives life

3 Ibid., p. 220. McGrath writes "was" because the thesis of his book is that atheism is no longer something that people subscribe to. It is a thing of the past.

4 Johnson, Paul, The Quest for God: A Personal Pilgrimage, Weidenfeld and Nicolson, London 1996, p. 2.

5 McGrath, Alister E., A Brief History of Heaven, Blackwell Publishing, Oxford 2003, p. 73.

6 Baggini, Julian, Atheism: A Very Short Introduction, Oxford University Press, Oxford 2003, p. 3. 
without reference to such a being. A theist is one who asserts the existence of such a creator. Any discussion of atheism, then, is necessarily a discussion of theism." ${ }^{7}$ So, in contrast to Baggini, Le Poidevin asserts that atheism is related to a specific concept of god: god as a personal and transcendent creator of the universe. According to Le Poidevin, atheism also implies a conscious and explicit position in the sense that simply living a life without God is not sufficient to call someone an "atheist."

We find the same contrast between theism and atheism in Daniel Harbour who writes: "Atheism is the plausible and probably correct belief that God does not exist. Opposed to atheism, there is theism, the implausible and probably incorrect view that God does exist." ${ }^{8}$

Atheism is generally considered to be an integral part of the tradition of the secular outlook. In what follows I will delineate what seems to me a defensible approach to atheism. Nevertheless, as I will try to show, few people approach atheism the way I do. Atheism has negative overtones. That does not make it necessarily untrue, of course, but the forces united against atheism as a creed, voiced by McGrath, Johnson, and many other detractors, are so formidable, and the misunderstandings about atheism so widespread, that it seems advisable to be somewhat cautious in using the term. In any case one should not identify the secular outlook entirely with atheism. ${ }^{9}$ It would surely be wrong to say that if atheism goes, the secular outlook goes. That, at least, will be my conclusion. Secularism is not atheism. Most atheists are secularists. ${ }^{10}$ Not all secularists are atheists. Atheism is about the existence of God. Secularism is about the role of religion in public life and about the way we should legitimize our moral commitments. But let us start with a defensible approach to atheism.

\section{The Alpha Privative}

I recommend the terminology used by Le Poidevin and Harbour. Atheism is a-theism. So: "a," hyphen, "theism." An atheist is someone who does not subscribe to the central tenets of theism. The "a" is an alpha privative, it denies what follows. So an atheist denies what a theist tries to assert.

Le Poidevin, Robin, Arguing for Atheism: An Introduction to the Philosophy of Religion, Routledge, London 1996, p. xvii.

8 Harbour, Daniel, An Intelligent Person's Guide to Atheism, Duckworth, London 2001, p. 1.

9 See also: Grayling, A.C., Ideas that Matter: A Personal Guide for the 21st Century, Weidenfeld \& Nicholson, London 2009, p. 334: "Secularism should be distinguished from both atheism and humanism."

10 As Grayling, ibid., writes: it would be "odd to find an atheist who was an anti-secularist." 
Someone who is a-religious is simply what it says: not religious. It is not the case that by denying a religion you, by some magic trick, invent a religion of your own: the religion of irreligious or a-religious people. Atheism is no more a religion than not playing chess is a hobby. Perhaps this sounds like a commonplace, nevertheless it is necessary to state it. Atheists are often considered to be driven by a religious impulse: the religious impulse to deny religion. Denying religion is in itself a religion, it is said. As a matter of fact, we have seen this with McGrath. I consider this form of reasoning to be a strange rhetorical trick.

Because atheism is the denial of theism, every tract on atheism should also address the question "what is theism?" Theism is the same as - monotheism, which is the more current term. Theists are adherents of one of the three theistic religions: Judaism, Christianity and Islam. Theists believe in one god. That makes the word "monotheism," strictly speaking, a pleonasm. But theism is more than belief in one god; it also requires a conception of a specific god. God, according to theists, is good. And not only "good" in the sense you and I can be good, but perfectly good. Someone who identifies God with evil ("the supreme evil, God"), as the great Victorian poet Algernon Charles Swinburne (1837-1909) did, ${ }^{11}$ cannot be a theist. The god of Jews, Christians and Muslims is eo ipso good.

Goodness is not the only attribute of the theistic god. He is eternal, the creator of the universe, almighty, transcendent, omniscient, holy, and personal. Western theology has tried to reflect on those characteristics and construe a concept of God that is consistent (I will elaborate on these attributes in the first section of Chapter 4, Pope Benedict XVI on the Apostles' Creed). ${ }^{12}$

\section{Atheism and Liberal Concepts of God}

Theism as outlined above is something different from religious belief in general. So atheism in the sense outlined here is not opposed to religion as such. Atheism is concerned with one specific concept of god: the theistic god. The theistic god has a name and this is written with a capital: God. ${ }^{13}$ At face value it may be strange to limit atheism so that it is opposed only

\footnotetext{
11 Swinburne quoted in: Bury, A History of the Freedom of Thought, Thornton Butterworth, London 1932 (1913), p. 208. See also: Hargreaves, H.A., "Swinburne's Greek Plays and God, 'The Supreme Evil,'” Modern Language Notes, 76, no. 7 (1961), pp. 607-616.

12 See also: McGrath, Alister E., Christian Theology: An Introduction, Blackwell, Oxford 1994. And for the way the theistic conception of god has developed: Tilghman, B.R., An Introduction to the Philosophy of Religion, Blackwell, Oxford 1994, pp. 10-46.

13 See: Wright, Robert, The Evolution of God, Little, Brown and Company, New York, Boston, London 2009, p. 209: "God with a Capital G."
} 
to the theistic concept of god and not to all the other gods that have been venerated by man. Buddhists or Hindus subscribe to polytheistic apprehensions of the divine. Should not they be included in the atheist rejection of the divine, as they are in Baggini's definition of atheism, mentioned above? I think not and I will now spell out my reasons for using the narrow definition.

The best way to make my position clear is by means of an example. There are people who are in awe of, or even venerate, vague and wide dimensions of reality that they identify as "the totally other" (das ganz Andere).${ }^{14}$ Or who refer to a particular mystical experience. ${ }^{15}$ There are people and theologians who claim to worship "the absolute" or "ultimate reality" or the "unsearchable region out of which all phenomena spring." 16 C.S. Lewis (1898-1963), who was not particularly fond of this approach, called it "Christianity-and-water." 17 Take the theologian Paul Tillich (1886-1965). In his book Dynamics of Faith (1958) Tillich tells us: "The fundamental symbol of our ultimate concern is God." ${ }^{18}$ Here God is not a person, not a father, not a creator, but a symbol. You cannot pray to a symbol, so it would seem. A symbol does not lead the Jewish people through the desert. A symbol does not reveal the Ten Commandments to Moses on Mount Sinai, and symbols do not have sons to be sent to the earth to atone for our sins. The concept of God advocated by Tillich is completely different from the one that theistic religions proclaim. Should an atheist also be opposed to (or deny) the reality of such symbols? My answer is "no."

Another theologian, J.A.T. Robinson (1919-1983), in his book Honest to God (1963) criticizes the conception of God as a supernatural being "out there" or the "old man in the sky." God, so Robinson proclaims is, by definition, "ultimate reality." Robinson adds that it is meaningless to ask whether God exists. The only question we can fruitfully pose is: what does that ultimate reality look like? ${ }^{19}$

We also find ideas like those of Robinson and Tillich in the work of the German theologian and philosopher of religion Rudolf Otto (1869-1937) ${ }^{20}$

14 As is the case with the German philosopher Max Horkheimer. See: Horkheimer, Max, Die Sehnsucht nach dem ganz Anderen, Ein Interview mit Kommentar von Helmut Gumnior [Longing for the Totally Other, an Interview with Commentary by Helmut Gumnior], Furche Verlag, Hamburg 1975 (1970).

15 For several approaches see: Happold, F.C. (ed.), Mysticism, A Study and an Anthology, Penguin Books, Harmondsworth 1979 (1963).

16 Caird, John, An Introduction to the Philosophy of Religion, James Maclehose and Sons, Glasgow 1894, p. 8.

17 See: McGrath, A Brief History of Heaven, p. 132.

18 Tillich, Paul, Dynamics of Faith, Harper Torchbooks, New York 1958, p. 45.

19 Robinson, John A.T., Honest to God, The Westminster Press, Philadelphia 1963, p. 29.

20 Otto, Rudolf, The Idea of the Holy: An Inquiry into the Non-rational Factor in the Idea of the Divine, second edition, Oxford University Press, New York 1958. 
and Friedrich Daniel Ernst Schleiermacher (1768-1834). ${ }^{21}$ I will not be concerned with conceptions of the divine as advocated by those liberal theologians (although Schleiermacher's hermeneutics will be discussed in Chapter 4). Why not?

First: a possible discussion with Robinson and Tillich would probably not deal with theism or atheism but with logic, methodology, or the philosophy of science. The discussion would focus on the question of whether it is fruitful to discuss such vague concepts as "ultimate reality." What is "reality"? Is the love for my daughter "reality" or "a reality"? Is the dream I had last night part of "reality"? These are all difficult problems that have to be solved first if one is to discuss whether God is "reality" (or "a reality"). And what characteristics should reality have if it is to be "ultimate"? And what justification do we have for identifying such vague concepts with "God"? Would not that be a kind of verbal inflation? Is what Tillich and Robinson do, not to present a kind of sophisticated atheism? ${ }^{22}$ Philosopher Paul Kurtz (1925- ) coined the word "igtheism" to denote what he thinks underlies the theism of many theologians. The prefix "ig" is derived from the word ignorant. Kurtz argues that when theologians speak in woolly abstractions about the "ground of being" they are really employing murky language as a dodge to cover up our ignorance of how the universe actually operates. ${ }^{23}$

Suppose someone is so completely immersed in fishing that his "ultimate concern" lies in his hobby. During Sunday service this person sits at the side of the lake enjoying his favorite sport. Would this make fishing his "religion"? Of course not. Following that semantic strategy would amount to enormous verbal inflation. The eighteenth-century freethinker and sexual debaucher the Marquis de Sade (1740-1814) would have sadistic sex as his "religion." Youngsters who idolize Justin Timberlake (1981- ) would be the members of a new "religious" sect.

Perhaps for sociologists of religion, trying to be as neutral as they can towards the different manifestations of "God," "religion," and the "divine," this may be an interesting approach. But should it therefore be our leading perspective in every other context? This may be doubted, and this doubt is

\footnotetext{
21 Schleiermacher, Friedrich, On Religion: Speeches to its Cultured Despisers, Cambridge University Press, Cambridge 1996.

22 One of the most severe criticisms of the father of liberal theology, Schleiermacher, stems from J.M. Robertson who writes that the work of Schleiermacher "did little harm save insofar as it fostered the German proclivity to the nebulous in thought and language, and partly encouraged the normal resistance to critical thought." See: Robertson, J.M., A History of Freethought in the Nineteenth Century, Vol. I, Watts \& Co., London 1929, p. 49.

${ }_{23}$ In: Kurtz, Paul, The New Skepticism: Inquiry and Reliable Knowledge, Prometheus Books, Amherst, NY 1992 and: Cooke, Bill, Dictionary of Atheism, Skepticism, and Humanism, Prometheus Books, Amherst, NY 2006, p. 277.
} 
highly relevant for atheism. An atheist, so it may be safely contended, is primarily concerned with one specific religious tradition. He is concerned with the idea of a personal, almighty, omniscient, and perfectly benevolent god. The concept of "atheism" I try to defend in this book acknowledges that it is difficult, if not impossible, and also useless to develop an argument against all the different concepts of god and religion that are sometimes defended. The only thing an atheist can do is to oppose the kind of discourse that makes it impossible to discern under what circumstances one can legitimately say "I am not religious." If everybody is "religious" but only the content of that religion varies, the word "religion" has lost all meaning.

Philosopher Roger Scruton (1944- ) contributes to the inflation of the word "religion" when he writes: "We have cults like football, sacrificial offerings like Princess Diana and improvised saints like Linda McCartney." ${ }^{24}$ He also speaks about "the new secular religion of human rights" and continues: "I call it a religion because it seems to occupy the place vacated by faith. It tells us that we are the centre of the universe, that we are under no call to obedience, but that the world is ordered in accordance with our rights." ${ }^{25}$ Such language can draw our attention to certain similarities between football and religion in the sense of one of the world's religions, but we should be careful not to identify those phenomena as "religion."

To illustrate this, let me present a last example in the form of a dialogue. Suppose someone says "God is love" and the subsequent dialogue evolves:

"Do you mean love is one aspect of the divine being?"

"No, I mean God is love; God is identical with love."

"But in that case God can not be a person."

"No, indeed."

When an atheist opposes the statement "God is love" this is not because he wants to deny the importance of love, but because he deems it inappropriate to mix up this human emotion with the divine being that Judaism, Christianity, and Islam traditionally refer to as the transcendent, personal, almighty and perfectly good god, viz. God. In other words there are good reasons for maintaining the limited conception of "atheism." "Atheism" is nothing more than the denial of the claims of theism.

\section{Atheism as an Unpopular Position}

Atheism has always been a very unpopular position, to say the least. Theologian and classics scholar Richard Bentley (1662-1742) wrote in 1724

24 Scruton, Roger, Gentle Regrets: Thoughts from a Life, Continuum, London 2005, p. 232.

25 Ibid., p. 238. 
in Eight Sermons that an atheist can never be a loyal friend. ${ }^{26} \mathrm{He}$ also proclaimed that an affective relation is impossible with an atheist and that an atheist can never be a loyal citizen. The Protestant theologian Robert Flint (1838-1910) asserted that in every country where atheism became dominant, "national decay and disaster" would be the result. In France, it was impossible to publish books defending atheism until the French Revolution. That is why famous atheist philosophers, such as the Baron d'Holbach (1723-1789) and Denis Diderot (1713-1784), wrote anonymously. ${ }^{27}$

In classical antiquity the attitude towards unbelievers was more tolerant, but in Greek society too there was no complete freedom of religion (including the possibility of rejecting a religion). Plato (c. 428-347 вСЕ) discerned four categories of "atheists," but all deserved the punishment of death. ${ }^{28}$

The attitude towards atheism in the middle ages was, as one would expect, even more severe. Thomas Aquinas (c. 1225-1274), like Plato, proposed the death penalty for atheists. ${ }^{29}$ Even John Locke (1632-1704), the writer of several treatises defending tolerance, was vehemently opposed to atheists. One of the reasons he put forward was that promises made by atheists would not be kept. When d'Holbach's Le système de la nature [The System of Nature] (1770) was published, the hangman complained that only the book could be burned and not the author.

Obviously, past atheists had to be cautious. And Joseph McCabe (18671955) rightly censured the Danish philologist A.B. Drachmann (18601935), writer of a book entitled Atheism in Pagan Antiquity (1922), for not having taken this sufficiently into account. ${ }^{30}$ According to Drachmann, only ten known Greek and Roman thinkers, and few others, had been

26 In this overview of reactions towards atheism I am indebted to: Edwards, Paul, "Atheism," in: The Encyclopedia of Philosophy, Paul Edwards, ed., Vol. I, MacMillan \& The Free Press, New York 1967, pp. 174-189; Edwards, Paul, "God and the Philosophers. Part I: From Aristotle to Locke," Free Inquiry, 18, no. 3, 1998; Edwards, Paul, "God and the Philosophers. Part II: From Fideism to Pragmatism," Free Inquiry, 18, no. 4, 1998; Edwards, Paul, God and the Philosophers, Introduction by Timothy J. Madigan, Prometheus Books, Amherst, NY 2009; Nagel, Ernest, "A Defense of Atheism," in: Paul Edwards and Arthur Pap, eds., A Modern Introduction to Philosophy, revised edition, The Free Press, Collier-MacMillan, New York 1967, pp. 460-473.

27 Paul-Henri Thiry, Baron d'Holbach was the pre-eminent eighteenth-century theoretician of atheism and the author of, among other works, a Critical History of Jesus Christ and The Sacred Contagion, a Natural History of Superstition. For other authors, see: Graille, Patrick, \& Kozul, Mladen, Discours anti-religieux français du dix-huitième siècle. Du curé Meslier au Marquis de Sade [French Eighteenth-Century Anti-Religious Texts. From the Curé Meslier to the Marquis de Sade], Les Presses de l'Université Laval, Paris 2003.

28 Plato, The Laws, Book X, and: Schofield, Malcolm, Plato: Political Philosophy, Oxford University Press, Oxford 2006, p. 313.

29 Summa Theologica, 2-2. I-16.

30 Drachmann, A.B., Atheism in Pagan Antiquity, Kessinger Publishing, Whitefish 2005 (1922). 
atheists over a period of more than a thousand years. McCabe calls such a remark misleading: "Professor Drachmann means that very few stood out in the cities of Greece and said that the gods did not exist." But what can you expect after Socrates had been condemned to drink the hemlock ?11 $^{31}$

What McCabe wrote about the Greek philosophers in particular could be said about other philosophers as well. A case in point is that of Spinoza (1632-1677), nowadays considered to be one of the most important influences on the European Enlightenment. ${ }^{32}$ Because of his unorthodox views he was excommunicated from the Jewish community in 1656, and he changed his name from Baruch to Benedict. In 1670 his Tractatus Theologico-Politicus was published - anonymously. His Ethica (1677) was only published after his death. The Ethics rejected the idea of a personal creator, free will, and personal immortality. On the criteria outlined before, Spinoza should be characterized as an atheist.

Like Kant and Hume, ${ }^{33}$ Spinoza was extremely careful not to offend the authorities. He was well aware that freedom of speech (or freedom of expression) was far from accepted even in a relatively free country such as the Dutch Republic. The most vehement reactions to Spinozistic doctrines were directed at disciples of Spinoza, such as Adriaan Koerbagh.

Adriaan Koerbagh (1632-1669) is regarded as one of the most radical thinkers of the early Enlightenment. ${ }^{34}$ During the early 1660s Adriaan and his brother Johannes Koerbagh (1634-1672) became strongly involved with the heterodox Spinozistic circles in Amsterdam, and eventually with Spinoza himself. In 1668 Adriaan published two books, Bloemhof and Ligt, which struck at the very roots of Christianity. Adriaan, however, did what Spinoza himself was always too cautious to do: he published in the vernacular language. The reason for this was that he wanted to enlighten not only the

31 McCabe, Joseph, The Existence of God, Watts \& Co., London 1933, p. 31.

32 See: Israel, Jonathan I., Radical Enlightenment. Philosophy and the Making of Modernity 1650-1750, Oxford University Press, Oxford 2001; Israel, Jonathan I., Enlightenment Contested. Philosophy, Modernity, and the Emancipation of Man 1670-1752, Oxford University Press, Oxford 2006.

33 See on this: Mossner, Ernest C., "The Enigma of Hume," Mind, New Series, 45, no. 179 1936, pp. 334-349; Mossner, Ernest C., "The Religion of David Hume," Journal of the History of Ideas, 39, no. 4 1970, pp. 653-663. But, for all his cautiousness, Hume could not avoid a reputation for being a radical. "Throughout his life he would be dogged with the unfair accusation of atheism," writes Roderick Graham in The Great Infidel: A Life of David Hume, John Donald, Edinburgh 2004, p. 27. See also: Ross, J.M., "Introduction," in: Cicero, The Nature of the Gods, translated by Horace C.P. McGregor, Penguin Books, London 1972, pp. 7-63, p. 60: "Hume was a complete sceptic in religion but felt he had to cast his work in dialogue form and pay verbal respect to current religious beliefs because otherwise he could never have got a hearing in eighteenth-century Scotland."

34 Wielema, M.R., “Adriaan Koerbagh," in: Wiep van Bunge, et al. (eds.), The Dictionary of Seventeenth and Eighteenth-Century Dutch Philosophers, Thoemmes Press, Bristol 2003, pp. 571-574. 
academic elite, but the common people as well. He was sentenced to ten years' imprisonment in the Rasphuis (a prison) in 1668 and subsequent banishment from Holland. He died in prison three months later due to the harsh conditions.

Although severe punishments such as those inflicted upon Koerbagh are unheard of in the modern Western world, that should not make us forget that atheism, or even changing one's religion for another religion, is sometimes still not possible without fear of death or serious reprisals. If the stake could still be invoked as the ultima ratio theologorum [theologians' final argument] it certainly would be, Schopenhauer remarked cynically. ${ }^{35}$

It is difficult to understand how atheism can ignite so much hatred in many people. Recent rebuttals of atheism usually try to credit it with colossal pretensions. This is, for instance, the case with a recent wave of criticism directed against the so-called "New Atheism" of Richard Dawkins, ${ }^{36}$ Daniel Dennett, ${ }^{37}$ Sam Harris, ${ }^{38}$ Victor Stenger ${ }^{39}$ and Christopher Hitchens. ${ }^{40}$ One of those criticisms contains the following sentence:

Those who believe they know how to bring about a conclusion to life seek to eradicate all other schemes for human perfection. These competing visions, in their eyes, pollute society, lead people astray, and stymie the ultimate possibilities of human happiness. The new atheists, like all true believers, want these competing visions destroyed. ${ }^{41}$

Destroyed? These are very strange ideas. The average atheist, like Spinoza or Hume, is far removed from the fanatic frame of mind that this author associates with atheism. Apparently, atheists are not only feared but hated.

Atheism - or rather charges of atheism - can still pose great problems for the writers involved. The most serious recent attack on the principle of freedom of thought and religion was perpetrated by the Iranian cleric Ayatollah Khomeini (1902-1989). If Khomeini had had his way, the British writer Salman Rushdie would have been killed for writing a novel. ${ }^{42}$

35 Schopenhauer, Arthur, Die Welt als Wille und Vorstellung [The World as Will and Representation], II, Cotta-Verlag/Insel-Verlag, Stuttgart/Frankfurt am Main 1976, p. 212.

36 Dawkins, Richard, The God Delusion, Black Swan, Transworld Publishers, London 2006.

37 Dennett, Daniel C., Breaking the Spell. Religion as a Natural Phenomenon, Allen Lane, Penguin Books, New York 2006.

38 Harris, Sam, Letter to a Christian Nation, Alfred A. Knopf, New York 2006; Harris, Sam, The End of Faith: Religion, Terror, and the Future of Reason, The Free Press, London 2005.

39 Stenger, Victor J., The New Atheism: Taking a Stand for Science and Reason, Prometheus Books, Amherst, NY 2009.

40 Hitchens, Christopher, god is not Great.

41 Hedges, Chris, I Don't Believe in Atheists, The Free Press, New York 2008, p. 99.

42 Pipes, Daniel, The Rushdie Affair: The Novel, the Ayatollah, and the West, second edition with a postscript by Koenraad Elst, Transaction Publishers, New Brunswick (USA) and London (UK) 2003. 
The same fate might have befallen the Bengali novelist Taslima Nasreen (1962- ), who had to flee India for criticizing religion and openly advocating atheism. In the Middle East several people have, in fact, been killed by religious fanatics, for example, the Egyptian thinker Farag Foda (19461992). ${ }^{43}$ So, although atheism is not legally prohibited in many parts of the world, and is even protected by the clauses on freedom of speech, freedom of thought, freedom of religion and freedom of worship in declarations of human rights and national constitutions, this situation is far from effective in securing freedom of conscience and the right to free discussion. What these examples make clear is that those favoring free speech, freedom of conscience, and the right to critique (including criticism of religious ideas) have more to refer to than the well-known historical examples of religious violence against Giordano Bruno (1548-1600), burned at the stake in 1600, or Galileo Galilei (1564-1642), intimidated by the Church and placed under house arrest in 1633.

It is rather odd that even in the twenty-first century atheism is highly unpopular: "would you confess to atheism in Texas, let alone Jeddah?" two writers of a recent overview of the comeback of religion in the public arena ask us. ${ }^{44}$ It seems that the nature of the rejection of atheism has changed, but there still is, so it seems, a widespread condemnation of it. In the eighteenth and nineteenth centuries the atheist was criticized because his worldview was said to undermine sound morals and deprive life of meaning. The contemporary complaints are that atheists show no "respect" for other people's religion or do not want to enter into "dialogue" with believers. Other complaints frequently voiced are that atheists are "polarizing" society or are "just as dogmatic" as religious fundamentalists.

These complaints are hardly convincing. Philosopher A.C. Grayling (1949- ) seems right when he says: "Religious apologists charge the nonreligious with being 'fundamentalist' if they attack religion too robustly." 45 He continues with the contention that "it is time to reverse the prevailing notion that religious commitment is intrinsically deserving of respect, and that it should be handled with kid gloves and protected by custom and in some cases law against criticism and ridicule." ${ }^{46}$ His point of view regarding religious criticism is that "nothing that people choose in the way of politics, lifestyle or religion should be immune from criticism and (when, as so often

43 See on this: Jansen, Johannes J.G., The Dual Nature of Islamic Fundamentalism, Cornell University Press, Ithaca, New York 1997, pp. 113-116.

44 Micklethwait, John, and Wooldridge, Adrian, God Is Back: How the Global Rise of Faith Is Changing the World, Allen Lane, Penguin Books, London 2009, p. 26.

45 Grayling, A.C., Against All Gods: Six Polemics on Religion and an Essay on Kindness, Oberon Books, London 2007, p. 7.

46 Ibid. p. 15. 
it does, it merits it) ridicule." ${ }^{\prime 7}$ Dawkins makes the same point. He castigates the view that "religious faith is particularly vulnerable to offence and should be protected by an abnormally thick wall of respect, in a different class from the respect that any human being should pay to any other." 48 He goes on:

I am not in favor of offending or hurting anyone just for the sake of it. But I am intrigued and mystified by the disproportionate privileging of religion in our otherwise secular societies. All politicians must be used to disrespectful cartoons of their faces, and nobody riots in their defense. What is so special about religion that we grant it such uniquely privileged respect? ${ }^{39}$

But Dawkins' attitude is far from common nowadays.

Against the background of the universal unpopularity of atheism it is hardly surprising that the epithet is usually rejected and seldom vindicated. Only a few philosophers have insisted on being called "atheists." ${ }^{50}$ Most people, Hume being one example, have been labeled "atheists" by their opponents, often with unfortunate consequences. Lady Mary Wortley Montagu (1689-1762) confided that the philosophy of Hume could be characterized as follows: "Take the 'not' out of the Decalogue and put it in the Creed." ${ }^{51}$

\section{A Definition of Atheism}

\section{Atheism as a-theism}

So far I have been mainly concerned with what atheism is not. Yet it is equally important to specify some of the implications of what atheism is. First we have to emphasize its intimate relation with theism. Philosopher Ernest Nagel (1901-1985) puts it as follows in his A Defense of Atheism (1957): "I shall understand by 'atheism' a critique and a denial of the major claims of all varieties of theism." ${ }^{2}$ And theism is the view that holds that

47 Ibid., p. 19.

48 Dawkins, The God Delusion, p. 42.

49 Ibid., p. 50.

50 Edwards, "Atheism," p. 175.

51 Quoted in Beck, Lewis White, "Hume," in: Lewis White Beck, Six Secular Philosophers. Religious Thought of Spinoza, Hume, Kant, Nietzsche, William James and Santayana, Thoemmes Press, Bristol 1997, pp. 41-63, p. 41.

52 Nagel, Ernest, "A Defense of Atheism," in: Paul Edwards and Arthur Pap, eds., A Modern Introduction to Philosophy, revised edition, The Free Press, Collier-MacMillan, New York 1967 (1957), p. 460. 
the "heavens and the earth and all that they contain owe their existence and continuance in existence to the wisdom and will of a supreme, selfconsistent, omnipotent, omniscient, righteous, and benevolent being, who is distinct from, and independent of, what he has created," as one author has stipulated..$^{53}$

In this quote we encounter the elements of theism that were introduced before: omnipotence, omniscience, perfect righteousness, benevolence. So an atheist is someone who denies the existence of a god with characteristics as set out above. In other words: he denies the existence of "God."

This is the approach we find in Le Poidevin, Harbour, Nagel, and also Paul Edwards (1923-2004). Edwards writes: “On our definition an 'atheist' is a person who rejects belief in God." ${ }^{54}$ So an atheist (as a-theist) is not someone who rejects belief in gods (without further specification) but only belief in the existence of God; God being a god with certain characteristics. What are those characteristics? Edwards states: "All the believers in the question have characterized God as a supreme personal being who is the creator or the ground of the universe and who, whatever his other attributes may be, is at the very least immensely powerful, highly intelligent and very good, loving, and just." 55

Often atheism is characterized as a broader position. Michael Martin (1932- ), one of the most important contemporary authors on atheism, writes: "In its broader sense atheism, from the Greek $a$ ('without') and theos ('deity'), standardly refers to the denial of the existence of any god or gods." " "Atheism: an attitude of skepticism toward claims of the existence of any sort of God or gods." ${ }^{57}$ The broader definition is also adopted by George H. Smith (1949- ), a passionate atheist himself, who writes: "An atheist is a person who does not believe in any god or number of gods." ${ }^{58}$ Nevertheless Smith adds that "some theists" have been called "atheists" for disbelieving

53 That author was Robert Flint, Professor of Divinity at the University of Edinburgh; see: ibid., p. 461.

54 Edwards, “Atheism,” p. 175.

55 Ibid.

56 Martin, Michael, “Atheism,” in: Tom Flynn, ed., The New Encyclopedia of Unbelief, Prometheus Books, Amherst, NY 2007, pp. 89-96, p. 88. See also: Martin, Michael, "Atheism Defined and Contrasted," in: Michael Martin, Atheism: A Philosophical Justification, Temple University Press, Philadelphia 1990, pp. 463-476.

57 Cooke, Bill, "Atheism," in: Bill Cooke, Dictionary of Atheism, Skepticism, \& Humanism, Prometheus Books, Amherst, NY 2006, pp. 49-50, p. 49. See also: Geisler, Norman L., and Turek, Frank, I Don't Have Enough Faith to Be an Atheist, Crossway Books, Wheaton, Illinois 2004, p. 22: "An atheist, of course, is someone who does not believe in any type of God."

58 Smith, George H., Why Atheism?, Prometheus Books, Amherst, NY 2000, p. 19. "Theism” is defined by Smith as: "belief in god or gods." See: Smith, George H., Atheism: The Case Against God, Prometheus Books, Buffalo, NY, 1989 (1979), p. 7. 
in the god (or gods) of the "orthodox majority." 59 With that last qualification, the god of the orthodox majority, the more narrow definition of atheism comes into focus. This is also the case when Martin notes that:

in Western society the term atheism has most frequently been used to refer to the denial of theism, in particular Judeo-Christian theism. This is the position that a being that is all-powerful, all-knowing, and all-good exists who is the creator of the universe and who takes an active interest in human concerns, and guides his creatures by revelation. ${ }^{60}$

That more limited or narrow definition of atheism ("atheism" as the term has most frequently been used in Western society, according to Martin $)^{61}$ or, what I have called, atheism as a-theism, has some advantages but also some disadvantages vis-à-vis the broader sense (atheism as the rejection of any god or gods). Although I prefer the narrow definition of atheism, let's start with the disadvantages.

One obvious disadvantage of the limited definition is that it has some counter-intuitive effects. These are as follows.

On the basis of the more limited definition of atheism, polytheist conceptions are "atheist." From the perspective of atheism as a-theism, Greek and Roman polytheism, for instance, would have to be classified as "atheist." The depiction of ultimate reality as impersonal (which we find in the earlier Upanishads) would also be categorized "atheist." Theravada Buddhism and Jainism, which also reject a theistic creator god, would fall into the same category. ${ }^{62}$ Pantheism, being a rejection of a personal god, is "atheistic" from the perspective of atheism as a-theism as well. Spinoza was an atheist, from this point of view.

Many people find this puzzling.

An even more unacceptable consequence of the definition of atheism as a-theism is that liberal conceptions of the divine would have to be qualified as "atheist." Spinoza would not be alone in being characterized as an atheist. The religious convictions of modern theologians such as John A.T.

59 Smith, Why Atheism?, p. 19. See also: "The term theism usually refers to the belief in a personal god or gods such as found in Judaism, Christianity, Islam, and Hinduism. Technically then, an atheist is someone who does not believe in the gods of these religions." In: Stenger, Victor J., The New Atheism: Taking a Stand for Science and Reason, Prometheus Books, Amherst NY 2009. p. 21. This is a somewhat eccentric definition of both theism and atheism because Stenger includes a polytheistic religion, Hinduism, under the heading of (mono)theism. 60 Martin, "Atheism," p. 88.

61 See also: "General Introduction," in: Martin, Michael, ed., The Cambridge Companion to Atheism, Cambridge University Press, Cambridge 2007, p. 1: "In modern times 'theism' has usually come to mean a belief in a personal God who takes an active interest in the world and who has given a special revelation to humans."

62 Martin, “Atheism,” p. 88. 
Robinson and Paul Tillich, whose work was mentioned before, would put them in the same camp. Some people find this deeply counterintuitive. From the perspective of liberal theology it is repugnant, for it would imply that only - what they like to call - the most orthodox and "fundamentalist" positions would be accepted as "theistic" and more liberal positions would become "atheist." That gives much too much ground to the fundamentalists, is a common objection.

This type of criticism might be illustrated by reference to the work of one of the most well-known representatives of the analytical tradition in the philosophy of religion: the Oxford philosopher Anthony John Patrick Kenny (1931- ).

Kenny gives a lucid summary of his views on religion in his book What I Believe (2006). ${ }^{63}$ Kenny was ordained a priest in 1955 , but he did not think that the existence of God could be demonstrated. This was a problem because pontifical doctoral candidates had to take an oath rejecting various modern heresies. The oath also included the statement that it was possible to demonstrate the existence of God ${ }^{64}$ After two years of priesthood he decided that he could no longer continue as a teacher of doctrines and moral precepts about whose validity he was increasingly doubtful. ${ }^{65}$ That is why he obtained leave from the Pope to return to the lay state and had several academic posts in Oxford.

From 1969 to 1972 Kenny lectured on Natural Religion. He analyzed the relationship between the divine attributes: omniscience, omnipotence, benevolence. His view was this:

I argued that these three attributes were incompatible with one another, as could be seen by reflection on the relationship between divine power and human freedom. If God is to be omniscient about future human actions, then determinism must be true. If God is to escape responsibility for human wickedness, then determinism must be false. So there cannot be an omniscient, omnipotent, all good being. ${ }^{66}$

Kenny writes that he concluded from this that there cannot be such a thing as the God of scholastic or rationalist philosophy. Nevertheless, this did not bring him to the atheist position. Why not? Kenny answers: "I left the question open whether it is possible to conceive, and believe in, a God defined in less absolute terms." ${ }^{67}$

63 Kenny, Anthony, What I Believe, Continuum, London 2006.

64 Ibid., p. 5.

65 Ibid., p. 6.

66 Ibid., p. 8.

${ }^{67}$ Ibid. Perhaps Kenny's position is somewhat similar to that of the humanist as defined by Corliss Lamont (1902-1995). Lamont writes: "Speakers of the Moral Majority insist that all Humanists are pernicious atheists, although Humanists have more and more tended to call 
Is that a reasonable position to take? From the perspective of atheism as a-theism it is not. ${ }^{68}$ Kenny seems to think that he has only rejected the "God of scholastic or rationalist philosophy," but is that true? Hasn't he done much more? I think he has. He has rejected the idea of God as defended through the ages by the Church and also, I am inclined to think, God as He appears to us in some important passages in Holy Scripture.

Whether that last contention is true depends, of course, on the question of whether the attributes of God as defended by the Church have a firm basis in Scripture. In other words: is it true that Scripture presents us with an omniscient, benevolent, and omnipotent person? Or is the personal, omniscient, benevolent, and omnipotent God an invention of scholastic and rationalist philosophy, as Kenny seems to presuppose?

My impression is that the Church is on much firmer ground than liberal theologians like to acknowledge. In other words: I think the characteristics that the Church, the Church fathers and the scholastic philosophers have attributed to God, have a firm basis in Scripture. Scripture does not present us with a God who is limited in power, for instance.

A person who believes in the existence of a god with the characteristics described before is generally considered to be a "theist." That is not very controversial. The controversy centers on the other position: the atheistic one. How do we qualify the person who does not believe in that specific concept of god? A reasonable answer, so it seems to me (following Harbour, Nagel and Le Poidevin), is "atheist." So Kenny, so it seems to me, is an "atheist" in the sense outlined above.

Nevertheless, he is adamant about not adopting that epithet. Kenny himself is not a "theist," as he explains in chapters 4 and 5 of his book (those chapters are titled "Why I am Not a Theist I" and "Why I am Not a Theist II"), but in chapter 3 of his book he claims not to be an "atheist" either (chapter 3 is called "Why I am Not an Atheist").

What is the reason for his not wanting to adopt the term "atheism" as a designation for his position? That appears to be, as we have seen in the passage quoted above, that he "left the question open whether it is possible to conceive, and believe in, a God defined in less absolute terms." ${ }^{69}$

\footnotetext{
themselves nontheists or agnostics. Humanists find no adequate proof of a supernatural God functioning upon this earth and guiding the human race to a divine destiny; but the immensity of the universe makes them cautious about absolutely denying the existence of God among the billions of stars, many of which might have planets where some form of life could have developed." See: Lamont, Corliss, The Philosophy of Humanism, eighth edition, Humanist Press, Amherst, NY 1997 (1949), p. xxv.

68 Although some scholars defend the view that one can adhere to theism and yet reject the belief that an omnipotent God exists. See on this: Bishop, John, "Can There Be Alternative Concepts of God?” Nô̂s, 32, no. 2 (1998), pp. 174-188.

69 Kenny, What I Believe, p. 8.
} 
Kenny does not elaborate on what that "less absolute god" would look like. This question is literally "left open" in the sense that Kenny does not make the slightest attempt to provide us with any information about his conception of god, although the fact that he has this conception is the reason why he rejects the epithet "atheist."70

What he does, though, is to leave the reader with the expectation that there is research that could be done - as if that research might reveal that it is indeed possible to arrive at a god-conception on less absolutist terms. But is not that a little misleading? I am inclined to think it is. I say this because, in my opinion, no further research or deeper reflection is required to defend the position that a less absolutist conception of God is perfectly possible. One might remove, for instance, omnipotence from the characteristics of the theistic god. Or one might leave out benevolence. Either strategy would annul the difficulty of explaining the evil in the world and reconciling this with the idea of an omnipotent creator. As long as Kenny does not give us an idea of what his less absolutist conception of God looks like, we are not in a position to affirm or deny the existence of such a god or tell whether that god ought to be an object of veneration.

This implies that, as long as Kenny does not present a less absolute godconception of his own, we cannot adopt an a-theistic stance towards it. This is precisely my problem with the broader definition of atheism that some authors favor. As long as we do not have an idea what someone means when he or she refers to "god," there is no need to deny this god.

People can entertain some very curious notions of "god." The Marquis de Sade (1740-1814) could have said "sadistic sex is my god." Leopold von Sacher Masoch (1836-1895), whose name gives us the word "masochism," could have pointed to the divine experience of sexual submission to his mistress. After all, submissive sex was exactly where his ultimate commitment lay, and modern theologians use that as a definition of god or "religion." If we follow Paul Tillich's definition of faith as a state of being grasped by an ultimate concern, ${ }^{71}$ there is no reason to deny the Marquis de Sade or Leopold von Sacher Masoch the status of "religious" persons. Their gods are very different from the gods of most other people, but they are gods nonetheless, because they were the ultimate concern of their adherents. The relevant question seems to be this: "Is there some threshold for 'godliness' that one cannot transgress?" We may suppose that many people will reject definitions such as "god is sex," but on what grounds

70 Neither does he tell us what his definition of "atheism" is, by the way. Probably Kenny sees the atheist as someone who rejects belief in the existence of all gods (whatever their nature), as many other writers on the subject do.

71 See on this: Braaten, Carl E., "Paul Tillich and the Classical Christian Tradition," in: Paul Tillich, A History of Christian Thought From Its Judaic and Hellenistic Origins to Existentialism, A Touchstone Book, Simon and Schuster 1967, pp. xiii-xxxiv, p. xxviii. 
do they do this? Definitions like "god is love" are less unusual. Why? Is it because sex is considered less worthy than love? Or is it, perhaps, because the idea of God as presented in Holy Scripture manifests more love than sex?

Anyhow, in principle we can take the attitude that everybody is free to present and venerate his or her own conception of "god." We may even proclaim this to be the essence of religious freedom as enshrined in national constitutions and human rights declarations. One could say, for instance, "god is love" and because there is love in this world reject the epithet "atheist." One might say "god is truth." One might also say: "I believe in love" or "I believe in truth" and in doing so one might have presented conceptions of god in - to quote Kenny - "less absolute terms." But the question is, of course, should someone who denies the existence of "truth" or "love" be called an "atheist"? The answer is clearly "no." Someone who denies the existence of "truth" is a relativist or a nihilist, perhaps, but not an "atheist." The atheist does not deny everything that people may choose to call "god," but only "God."

One thing is clear. From the position of atheism as a-theism, the position taken by Nagel, Le Poidevin and others, Kenny is an "atheist." 72 On the basis of the broader definition of atheism (rejection of God and gods, whatever the nature of the god or gods may be) he obviously is not. But who would be?

Everybody is free to use his or her own definitions, but it does seem fair to say is that the limited definition of atheism is the more useful one because it seems appropriate to have a shorthand label for the position of someone who does not accept the central claims of theism as made by the Church on the basis of Holy Scripture. ${ }^{73}$

A Dictionary of Philosophy (1979), edited by Antony Flew (1923-2010), gives a succinct argument for the narrow definition of atheism as "the rejection of belief in God.” It states:

\footnotetext{
72 See also: Kenny, Anthony, The Unknown God: Agnostic Essays, Continuum, London 2004.

73 See also: Smith, George H., Why Atheism?, Prometheus Books, Amherst, NY 2000, p. 28: "Given the wide diversity of religious opinions, I have chosen to discuss Christianity throughout this book in order to focus my arguments. But most of my arguments also pertain to any religion (e.g. Islam and some forms of Judaism) that contains the following elements: (1) a doctrine of personal immortality, (2) a promise of salvation for those with orthodox (i.e. correct) belief, and (3) a belief that a least some knowledge necessary for salvation requires faith in divine revelation, knowledge that cannot otherwise be justified through reason alone. These elements constitute what is generally called a 'salvation religion' or a 'personal religion', so I shall use these labels interchangeably." What this all amounts to, in my view, is that, although Smith presents a broad definition of atheism (see the previous pages), his focus is on atheism in the narrow sense of the word, viz. the denial of the existence of the theistic god: God.
} 
It can be said with some point that atheism exists only in relation to some conception of deity, that the professed atheist can always reasonably be asked what God he denies, and that "God" covers so many different conceptions, from crude anthropomorphism to sophisticated ideas of an Infinite Substance or Ground of all Being, that everyone is perforce an atheist in relation to some of them. However, the label "atheist" is ordinarily, though probably not invariably, applied without qualification only to someone who denies God in any of the senses that current uses of the term allow. ${ }^{74}$

One may object that this narrow definition of "god" (god as God) was not the preoccupation of the majority of the philosophers and theologians of the Western tradition. So atheists focusing on the narrow definition of "god" are fighting a straw man, it is often said. But that is certainly not true. There is a long discussion of the nature of the theistic god in Western culture. Great philosophers and theologians like Plato, Aristotle, Cicero, Augustine, Boethius, Saadia, Avicenna, Anselm, Ghazali, Averroes, Maimonides, Thomas Aquinas, John Duns Scotus, William of Ockham, Martin Luther, Luis de Molina, Francisco Suárez, Thomas Hobbes, René Descartes, Blaise Pascal, Spinoza, Malebranche, Leibniz, Bayle, Berkeley, Voltaire, Paley, Hume, Kant, Hegel, Feuerbach, Darwin, Marx, Kierkegaard, Nietzsche, William James, Freud, Bertrand Russell, Alfred North Whitehead, C.S. Lewis, Alvin Plantinga, George Mavrodes, John Hick, Richard Swinburne, Daniel Dennett, and Richard Dawkins have all participated in a discussion on the existence of the theistic god, i.e. "God," with the characteristics as defined by the Church and based on the interpretation of Holy Scripture (Qur'an and Bible). That discussion through the ages was not a conversation about the different attitudes people had with regard to the ultimate ideals of life, but about the characteristics of the theistic god and in what sense these were compatible with each other and with other human ideals. If God knows the future, how can we have free will (Cicero)? What was God doing before He created the world (Augustine)? Must God, if he exists in the mind, also exist in reality (Anselm)? Can an omnipotent being be constrained by justice and goodness (Ghazali)? As the author of a recent overview of these arguments says:

thinkers from all three faiths [Judaism, Christianity and Islam] grappled with the general philosophical problems that needed solving if the great monotheism they were jointly constructing was to be viable, developing not merely sophisticated proofs of God's existence but also detailed conceptions of God's

74 Flew, Antony, ed., A Dictionary of Philosophy, Pan Books, Macmillan, London 1979, p. 28. See also: Jean Montenot, Encyclopédie de la Philosophie [Encyclopedia of Philosophy], La Pochotèque, Livre de Poche, Paris 2002, p. 106 using "atheism" as a term signifying the denial of the existence of God. 
various key attributes: omnipotence (or power), omniscience (or knowledge), perfect goodness, eternality, immutability, and so on. ${ }^{75}$

What this all amounts to is that discussions on the existence of God very often were discussions about the compatibility of the characteristics that in the theistic tradition are ascribed to God. Those who held those characteristics to be compatible were called "theists," those who did not "atheists." Discussing the existence of a god with no characteristics or characteristics too vague or undetermined to know much about seems a senseless activity. That implies that affirming the existence of such a "god" would be senseless and denying it would be equally so. Leslie Stephen (1832-1904) writes: "Dogmatic Atheism - the doctrine that there is no God, whatever may be meant by God - is, to say the least, a rare phase of opinion." " Whether it is indeed "rare," as Stephen suggests, is difficult to say, but that it is senseless is true. As I have said, that also has consequences for the affirmative position. It is similarly senseless to affirm the position of a "god" that we do not know anything about. So the liberal theologian who leaves the existence of such a god "open" is naturally allowed to do so, but this position is more problematic and also a little bit more trivial than it appears - or so the adherent of the conception of atheism as a-theism may contend. The atheistic approach, in the sense of the denial of the theistic conception of god (God), is also different from the approach of those atheists who see atheism as the rejection of all things supernatural. As we have seen, Julian Baggini (1968- ) defines atheism as "the belief that there is no God or gods." 77 But he goes further:

The atheist's rejection of belief in God is usually accompanied by a broader rejection of any supernatural or transcendental reality. For example an atheist does not usually believe in the existence of immortal souls, life after death, ghosts, or supernatural powers. ${ }^{78}$

Baggini acknowledges that "strictly speaking" an atheist could believe in any of these things and still remain an atheist, but, so he contends, "the arguments and ideas that sustain atheism tend naturally to rule out other beliefs in the supernatural or transcendental." 79

75 Pessin, Andrew, The God Question: What Famous Thinkers from Plato to Dawkins Have Said about the Divine, Oneworld, Oxford 2009, p. 20.

76 Stephen, Leslie, “An Agnostic's Apology,” Fortnightly Review, Vol. XXV, 1876, pp. 840-860, also in: Andrew Pyle, ed., Agnosticism: Contemporary Responses to Spencer and Huxley, Thoemmes Press, Bristol 1995, pp. 48-72, p. 48.

77 Baggini, Julian, Atheism: A Very Short Introduction, p. 3.

78 Ibid., p. 4.

79 Ibid. 
We find the same approach in the Dutch atheist Floris van den Berg (1973- ). Atheists do not believe in "god, in gods, not in dwarfs, elves, Martians, tarot cards, astrology." ${ }^{" 80}$ He makes a useful distinction between "narrow atheism" (which focuses on the three monotheist faiths) and "broad atheism" (rejecting all things supernatural) and considers himself to be a broad atheist. Broad atheism rejects all gods, all religions, and all forms of transcendentalism. ${ }^{81}$

\section{The negative character of atheism as a-theism}

So far I have been concerned with atheism as the denial of theism. The nature of that denial requires some comment though. Many rational nineteenth-century atheists were adamant that their doctrine was "negative" in the sense that they did no more than deny the claims of others. This "negative atheism" was, for instance, the focus of the most important advocate of atheism in the nineteenth century: Charles Bradlaugh (1833-1891). Besides being an atheist, Bradlaugh was a campaigner for progressive causes such as birth control, republicanism, the alleviation of poverty and the separation of Church and State. In his A Plea for Atheism (1864) he defined the essence of atheism thus:

The atheist does not say "There is no God," but he says: "I know not what you mean by God; I am without idea of God; the word 'God' is to me a sound conveying no clear or distinct affirmation. I do not deny God, because I cannot deny that of which, I have no conception, and the conception of which by its affirmer, is so imperfect that he is unable to define it to me." ${ }^{82}$

Another classic thinker in the atheist tradition was G.W. Foote (18501915), editor of the Freethinker and also the author of many books and

80 Berg, Floris van den, Hoe komen we van religie af? Een ongemakkelijke liberale paradox [How Do We Get Away from Religion? An Uncomfortable Liberal Paradox], Houtekiet/Atlas, Antwerpen 2009, p. 9.

81 Berg, Ibid., p. 9. See also: Thiselton, Anthony C., A Concise Encyclopedia of the Philosophy of Religion, Oneworld Publications, Oxford 2002, p. 18: "In the broadest terms, atheism denotes the denial of the existence of God." The distinction between small and broad atheism is also made by William Rowe. See: Rowe, William L., Philosophy of Religion: An Introduction, second edition, Wadsworth Publishing Company, Belmont, California 1993, pp. 14-15: "In the broader sense, a theist is someone who believes in the existence of a divine being or beings, even if his idea of the divine is quite different from the idea of God we have been describing. Similarly, in the broader sense of the term, an atheist is someone who rejects belief in every form of deity, not just the God of the traditional theologians."

82 Bradlaugh, Charles, "A Plea for Atheism" (1864) at: http://www.infidels.org/library/historical/charles_bradlaugh/plea_for_atheism.html (accessed 2/19/10), also in: Champion of Liberty: Charles Bradlaugh, Watts \& Co. and Pioneer Press, London 1933, and: Stein, Gordon, ed., An Anthology of Atheism and Rationalism, Prometheus Books, Buffalo, NY 1980, pp. 9-19, p. 10. 
articles on atheism. Foote was convicted of blasphemy and even sent to prison for his convictions. ${ }^{83} \mathrm{He}$ insisted that atheism is properly defined as the absence (or lack) of theistic belief, and not as the positive denial of God's existence. ${ }^{84} \mathrm{He}$ said: "The atheist is a person who is without belief in a god; that is all the 'A' before 'Theist' really means." ${ }^{\prime 85}$ According to the New Zealand historian and humanist Bill Cooke (1956- ) the philosophy of atheism was helped tremendously by the distinction between negative and positive atheism. "This had done a lot to clear up very old misconceptions about what atheism is really saying." ${ }^{86}$ So when Mel Thompson writes "belief in the existence of God ... is theism" and "the conviction that there is no such being is atheism," he exaggerates the ambitions of the atheist.

So far this "reasonable definition of atheism" or atheism as a-theism has two elements. On the one hand it is limited to a stance vis-à-vis the theistic god (and not the "less absolute" conceptions of the theistic god; we may call this, with Van den Berg, "narrow atheism"). On the other hand the nature of that stance is not subscribing to the position of his existence (in contrast to the pretension that you can disprove his existence).

This negative character of atheism is easily misunderstood, and that has to do with the ambiguities in the word "negative." "Negative," as used in connection with atheism, simply means "not affirmative." The atheist does not affirm the position of theism. But the word "negative" has all sorts of other meanings. A fact, situation, or experience that is "negative" is unpleasant, depressing, or harmful. If someone is "negative" or has a "negative" attitude, they consider only the bad aspects of a situation, rather than the good ones. Negative people are people who moan.

Critics of atheism usually capitalize on the second meaning of the word and reproach atheists for being "only negative." This is, for example, the case in a critique of secularism by the American scholar Brendan Sweetman. In Why Politics Needs Religion: The Place of Religious Arguments in the Public Square (2006), Sweetman argues that secularism is itself a kind of religion. ${ }^{87}$ It has its own morality and its own vision of the good life. $\mathrm{He}$

83 Herrick, Jim, "Foote, George William," in: Tom Flynn, ed., The New Encyclopedia of Unbelief, Prometheus Books, Amherst, NY 2007, pp. 332-333; Royle, Edward, "Foote, George William," in: Gordon Stein, ed., The Encyclopedia of Unbelief, Vol. I, Prometheus Books, Buffalo, NY 1985, pp. 224-226; Levy, Leonard W., Blasphemy: Verbal Offense against the Sacred from Moses to Salman Rushdie, The University of North Carolina Press, Chapel Hill 1993, pp. 481-485.

84 Smith, Why Atheism?, p. 23.

85 Quoted ibid., p. 23.

86 Cooke, Bill, Dictionary of Atheism, Skepticism, and Humanism, Prometheus Books, Amherst, NY 2006, p. 49. Cooke's book is an invaluable source of material for those interested in the secular tradition.

87 Sweetman, Brendan, Why Politics Needs Religion: The Place of Religious Arguments in the Public Square, Interversity Press, Downers Grove 2006. 
opposes the claim by secularists that only secular arguments should count in the public square. If Christians want to make a case against abortion or euthanasia, so Sweetman argues, they should be free to refer to the JudeoChristian tradition as something that motivates their commitment.

It is important at this point to comment on Sweetman's ideas, expounded in his book Religion (2007), ${ }^{88}$ on what he calls "an important distinction between negative atheism and positive atheism." 89 Up until the twentieth century, Sweetman argues, atheism was almost always presented as a "negative thesis" or position. It was negative in three ways.

First, the atheist defined his view in terms of what it was not, rather than in terms of what it was. "So in the past an atheist might say, when asked what he believed, that he did not think that God existed, or that he rejected religious morality, or that he did not follow his church's teaching, all claims about what he doesn't believe, not about what he does believe." 90

Second, the atheist often regarded himself negatively from a psychological point of view: belonging to a minority he couldn't avoid understanding his identity in terms of what he was not.

Third, the atheist defended his view negatively, viz. by "attacking religion and religious arguments for religious belief."

In the twentieth century "all this has changed," according to Sweetman, because atheists realized that a more "cultivated approach" was necessary. Subsequently, Sweetman formulates what "positive atheism" would look like, and in doing this he identifies "positive atheism" with "secularism."

Nowadays, a secularist is much more likely to present secularism as a positive thesis, one that identifies what he believes, rather than what he does not believe. As noted above, secularists will say they believe that human life is the outcome of a purely random, naturalistic process (evolution), and that all reality is physical. And, very important, their defense of these claims will not now consist simply of attacking the arguments for religious belief: they will try to offer positive arguments to support these views. ${ }^{92}$

I do not think this proposal in the field of terminology is much of an improvement. What Sweetman proposes is, first, to blur the distinction between atheism, secularism, and materialism. One may do this, of course, but the result is to introduce vagueness whereas clarity would be obtained by clearly distinguishing between these concepts. He also mixes up the two senses of "negativity": negative in the sense of "not affirmative" and nega-

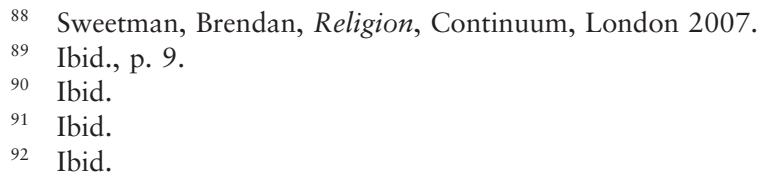


tive in the sense of "unpleasant" or "harmful." There is nothing wrong with simply not affirming a certain position. A pacifist is against war. Now, it is possible that pacifists have ideas about how a society without war would look, but what binds them is that they reject war. It seems idle to expect them to argue in favor of peace or to require them to tell us what additional "positive things" they aspire to besides absence of war. The meaning of a word is its use. Sweetman may propose all kinds of semantic distinctions, but I think it would be unfortunate if a clear semantic distinction that was held "up until the twentieth century" should fall into oblivion. If this sounds "conservative," so be it.

\section{Atheism does not have the burden of proof}

That brings us to an important consequence. This "negative approach" to atheism (defining atheism in terms of what it is not) has serious consequences for the burden of proof. Atheism in the sense outlined above simply denies the claims of theism. "Theists believe in God, while atheists do not have such a belief," as one author succinctly formulates it. ${ }^{93}$ Atheists do not pretend that they are able to prove that God does not exist. The atheist George H. Smith (1949- ) puts it as follows: "Atheism, in its basic form, is not a belief: it is the absence of belief." 94 That implies that the atheist does not defend the claim that he can prove God's non-existence, neither does he need to. "An atheist is not primarily a person who believes that a god does not exist; rather, he does not believe in the existence of a god." 95

I quote the claims of a self-confessed atheist at some length because his words contradict what is often alleged about atheists. Atheism is commonly presented as a special kind of "belief" that God does not exist. We find this in the definition of atheism offered by the philosopher of religion John Hick (1922- ). Hick writes: "atheism (not-God-ism) is the belief that there is no God of any kind." ${ }^{96}$ By attributing to atheism the pretension to reject gods of any kind, Hick advances claims that a more cautious atheist would be inclined to deny. ${ }^{97} \mathrm{He}$ also deviates from the approach of Nagel and

93 Johnson, B.C., The Atheist Debater's Handbook, Prometheus Books, Buffalo 1981, p. 11.

94 Smith, George H., Atheism. The Case against God, Prometheus Books, Buffalo, NY, 1989 (1979), p. 7.

95 Smith, Atheism, p. 7. The French atheist Paul Desalmand writes that the atheist does not try to demonstrate the non-existence of God because he knows this is an idle undertaking. He only wants to show the inconsistencies in the theist position. See: Desalmand, Paul, L'athéisme expliqué aux croyants [Atheism Explained to Believers], Le Navire en Pleine Ville, Paris 2007, p. 38 .

96 Hick, John, Philosophy of Religion, fourth edition, Prentice Hall International, Inc., London 1990 (1963), p. 5.

97 Baggini, whose definition of atheism was quoted before, is the exception here. 
Bradlaugh inasmuch as he suggests that the atheist must prove that God does not exist. This puts the atheist in a disadvantageous position, because if the atheist is not successful in this undertaking (and how can he ever achieve such an ambitious goal?), it will be commonly supposed that he has failed to substantiate his position. According to Smith, Nagel and other defenders of the "negative" approach, Hick's claim is an impossible claim to make. From their point of view, the only thing the atheist has to do is to wait until the theist has made his position clear. At that point the atheist can judge whether he is convinced by the theist's arguments. If he is not convinced, then atheism is the stronger position vis-à-vis theism.

Is that not the way we normally operate? I cannot prove that the world is not created by an elephant standing on the back of a tortoise, but why should I? It is up to the speaker who makes such a claim to prove his case.

The atheist's position may be summarized thus: atheism is a negative doctrine. The atheist is not convinced by the proofs of theism. This being the case, he does what every sensible person would do. He says "I am not a theist."

This falls far short of what Alister McGrath expects atheists to defend. McGrath gleefully ascribes colossal pretensions to atheists: "Atheism is the religion of the autonomous and rational human being, who believes that reason is able to uncover and express the deepest truths of the universe, from the mechanics of the rising sun to the nature and final destiny of humanity." ${ }^{98}$ So an atheist should have pretensions to solve the riddle of the universe. He should be able to express its "deepest truths." That kind of vocabulary does not make sense to atheists - at least not to the "reasonable" kind I have introduced. What special properties must a truth possess to be "deep" or even "the deepest"? Why should the atheist commit himself to speculations about the "final destiny of the universe"? McGrath mistakes atheism for a religion, in his case the religion of Christianity. Christianity claims to provide deep truths about the universe, for example that Jesus is the Son of God. ${ }^{99}$ Christianity also pretends to know what the final destiny of the universe is. The atheist does not profess to have any knowledge of this kind. ${ }^{100}$ Because McGrath thinks that atheism is the exact antithesis of Christian belief, he supposes that the atheist must also have certain opinions on these matters, but this is not the case. In reality we never hear atheists boasting about the discovery of deep truths and ideas about the final destiny of the universe. McGrath is probably confusing atheism with the worldview

\footnotetext{
98 McGrath, The Twilight of Atheism, p. 220.

99 See: Evans, Stephen C., The Historical Christ and The Jesus of Faith. The Incarnational Narrative as History, Clarendon Press, Oxford 1996.

100 See: Kirsch, Jonathan, A History of the End of the World: How the Most Controversial Book in the Bible Changed the Course of Western Civilization, HarperCollins, New York 2007.
} 
of Marxism-Leninism, of which a denial of God was one part. ${ }^{101}$ But no sane atheist would have such pretensions. The British philosopher Antony Flew (1923-2010) made this clear when he coined the expression: the presumption of atheism. ${ }^{102}$ Another way of putting it is that we should regard atheism as the default position. The theist has to prove his case. The historian J.B. Bury (1861-1927) presents this idea with a funny example:

If you were told that on a certain planet revolving round Sirius there is a race of donkeys who talk the English language and spend their time in discussing eugenetics, you could not disprove the statement, but would it, on that account, have any claim to be believed? ${ }^{103}$

That brings us to a fourth and final element of the concept of atheism.

\section{Atheism is an examined choice}

A fourth element of the atheist position is the psychological attitude of the atheist himself: atheism is considered to be an explicit intellectual choice. I hinted at this before when discussing Le Poidevin's thesis: simply living a life without God is not sufficient grounds for calling someone an "atheist."

Let me illustrate this with an example. Suppose someone tells us: "God? I don't know what that means. I've never thought about it." How should we characterize this view? Is the person expressing this view an "atheist"? Many of us would waver, and rightly so. What this person lacks is a conscious intellectual commitment. It would be strange to characterize this person as an "atheist." That is why children, by definition, cannot be "atheists" as d'Holbach once proclaimed they were. People who have never thought about God are pagans perhaps, not atheists.

This does not mean that atheism has to be what it is nowadays called "strident" or "militant." 104 One of the most frequently made comments on atheism is that atheists are "militant." This is also the reason why many people are reluctant to call themselves "atheists," fearing that they will be

101 See on this: Froese, Paul, "Forced Secularization in Soviet Russia: Why an Atheistic Monopoly Failed," in: Journal for the Scientific Study of Religion, 43:1 (2004), pp. 35-40. For the ideology of Marxism-Leninism in general: Acton, H.B., The Illusion of the Epoch: Marxism-Leninism as a Philosophical Creed, Routledge \& Kegan Paul, London 1962 (1955). 102 Flew, Antony, The Presumption of Atheism, and Other Philosophical Essays on God, Freedom and Immortality, Elek/Pemberton, London 1976. Flew caused some controversy because of a new development of his thinking in: Flew, Antony (with Roy Abraham Varghese), There Is a God: How the World's Most Notorious Atheist Changed His Mind, HarperCollins, New York 2007.

103 Bury, A History of the Freedom of Thought, p. 20.

104 See on this: Berman, David, A History of Atheism in Britain: From Hobbes to Russell, Routledge, London 1988, pp. 212-235: "Militant and Academic Atheism." 
considered impolite, unfriendly, and disrespectful. Some atheists are, indeed, straightforward in their opinions. The most well-known example is Richard Dawkins (1941- ). Dawkins advocates "actively disbelieving in God's existence." ${ }^{105}$ One passage from his bestselling book The God Delusion (2006) that is often referred to is this:

Imagine, with John Lennon, a world with no religion. Imagine no suicide bombers, no 9/11, no 7/7, no Crusades, no witch-hunts, no Gunpowder Plot, no Indian partition, no Israeli/Palestinian wars, no Serb/Croat/Muslim massacres, no persecution of Jews as "Christ-killer," no Northern Ireland "troubles," no "honor killings," no shiny-suited bouffant-haired televangelists fleecing gullible people of their money ("God wants you to give till it hurts"). Imagine no Taliban to blow up ancient statues, no public beheadings of blasphemers, no flogging of female skin for the crime of showing an inch of it. ${ }^{106}$

Another proponent of what is often referred to as "militant atheism" is Christopher Hitchens (1949-). Hitchens formulates the following four objections to religious faith in god is not Great (2007):

That it wholly misrepresents the origins of man and the cosmos, that because of this original error it manages to combine the maximum of servility with the maximum of solipsism, that it is both the result and the cause of dangerous sexual repression, and that it is ultimately grounded on wish-thinking. ${ }^{107}$

The New Atheism does not only have adherents in the anglophone world. The Dutch atheist Floris van den Berg (1973-) is a representative of the new current in the Netherlands. Van den Berg adopts the term "moral atheist," because he thinks religion is an impediment to individual freedom and autonomy. ${ }^{108}$ In a liberal democracy the state should not forbid, but discourage, religion. The attitude towards religion should be the same as towards smoking: you do not forbid it, but you do try to discourage people from associating themselves with it. In any case parents should not be in a position to cripple the minds of their children with their own religious preoccupations. ${ }^{109}$ Religious privileges should be abolished. ${ }^{110}$ "Where reli-

\footnotetext{
105 Dawkins, The God Delusion, p. 99.

106 Ibid., p. 24.

107 Hitchens, Christopher, god is not Great: How Religion Poisons Everything, Twelve, New York, Boston 2007, p. 4. In my terminology the title of this book should be: "God is not Great"; "god" with a capital "g." The reason is that the Hitchens's criticism is directed at a particular conception of "god": the theistic god.

108 Berg, Hoe komen we van religie af?, p. 16.

109 Ibid., p. 21.

110 Ibid., p. 24.
} 
gion is empowered, society transforms into a prison." ${ }^{111}$ Not believing is "normal," believing is "abnormal." 112 Atheists should raise their voices, van den Berg advocates; they should wear T-shirts with atheist texts. He organized the Dutch equivalent of the London buses that drove through the streets with the slogan:

There's probably no god,

Now stop worrying

And enjoy your life.

Another representative of the New Atheism is the American author Sam Harris (1967- ), whose The End of Faith (2004) emphasizes the destructive power of religious belief. He writes:

There seems ... to be a problem with some of our most cherished beliefs about the world: they are leading us, inexorably, to kill one another. A glance at history, or at the pages of any newspaper, reveals that ideas which divide one group of human beings from another, only to unite them in slaughter generally have their roots in religion. It seems that if our species ever eradicates itself through war, it will not be because it was written in the stars but because it was written in our books; it is what we do with words like "God" and "paradise" and "sin" in the present that will determine our future. ${ }^{113}$

This is all strong language and many people associate "atheism" with advocating atheism or with confrontational language. Is that right?

I do not think so. Atheism can be defended forcefully, as is the case in the work of the New Atheists, but Christianity can be as well. People like Martin Luther (1483-1546) or the contemporary Christian apologist Dinesh D'Souza ${ }^{114}$ (1961- ) defend Christianity in much the same way as Dawkins and Hitchens defend their atheism, and we should not mix up the way a point of view is defended with what is defended in itself. As long as there is a reasonable exchange of arguments (as there certainly is between people like Dawkins, Hitchens, Harris, and Dennett on the one hand and Alister McGrath and Dinesh D'Souza on the other) there is nothing wrong with a debate along these lines. On the contrary, I think philosopher of religion Charles Taliaferro is right when he says that the books by Dawkins and Dennett "have done a great deal of good by bringing the topic of religion to the fore of public discourse." 115 That compliment can be extended

111 Ibid., p. 30.

112 Ibid., p. 34.

113 Harris, Sam, The End of Faith: Religion, Terror, and the Future of Reason, The Free Press, London 2005 (2004), p. 12.

114 D'Souza, Dinesh, What's so Great about Christianity, Regnery Publishing, Inc., Washington, DC 2007.

115 Taliaferro, Charles, Philosophy of Religion, Oneworld, Oxford 2009, p. ix. 
to the work of Hitchens and Harris as well. The New Atheists have stimulated an enormous debate on the merits of theism that contrasts favorably with the woolly self-complacent abstractions of the liberal theologians that set the tone in the 1960s and 1970s.

This overview would not be complete without another allegation that is often voiced about atheism. Atheists, so some authors say, despise religion or religious believers. This is insinuated in the following words by philosopher of religion John D. Caputo (1940- ) who writes that he does not want to be "accused of behaving like an Aufklärer, like one more learned despiser of religion." 116

These words imply a highly negative and rhetorical vision of the Enlightenment as a movement that despises religion. But why should an Aufklärer [rationalist (from the Enlightenment)] despise religion? If you carefully analyze the arguments of the protagonists of religion and politely tell them you are not convinced, does that testify to a negative attitude? ${ }^{117}$ And if you do not locate the source of moral norms in God but in the nature of man, as Enlightenment philosophers did, ${ }^{118}$ are you then a "despiser" of religion? I do not think so and this rhetorical device should be unmasked for what it is: a cheap trick to intimidate critics into swallowing things that should not be swallowed.

\section{Motives for Atheism}

In this section I wish to conclude my reflections on the definition of atheism. The characteristics presented in the previous section are, basically, what the concept is all about. An atheist simply denies the claims of theism. As we have seen, we should not mix this up with the ways in which atheism can be defended. Nor should we fail to distinguish between what atheism is and the motives for atheism.

116 Caputo, John D., On Religion, Routledge, London 2001, p. 94.

117 Caputo continues with the remark that he does not "want to dismiss fundamentalist spirituality as so much nonsense." He says: "I want to settle inside this passion for the impossible, to rock with the rhythms of its divine madness, to sway with the joyous pulsations of the Word of God as it shakes the bodily frames of mortal coils of these whole-hearted believers. I want to dance and sing, not sneer!" Ibid., p. 95. What this means and if it means anything at all is difficult to say. Should we read this as a Dionysian glorification of irrationality? Is not dancing and singing an irresponsible reaction in this time of religious violence?

118 See: Larmore, Charles, "Beyond Religion and Enlightenment," San Diego Law Review, 30 (1993), pp. 799-815, p. 803: "Despite the obvious danger in defining a movement so complex as the Enlightenment, I believe we may consider as one of its most important legacies the project of locating the source of moral norms, no longer in God, but in the nature of Man.” 
This is - to my mind - what is neglected in the attempt to define atheism by the Irish philosopher and sociologist Patrick Masterson (1936- ). Masterson writes in his book Atheism and Alienation (1971) that the emphasis of contemporary atheists has shifted from a critique of the proofs for the existence of God to the rejection of the properties traditionally attributed to Him. The atheism of his day, so he continues, consists chiefly in asserting the impossibility of the coexistence of finite and infinite being. What contemporary atheists object to is that "the affirmation of God as infinite being necessarily implies the devaluation of finite being and, in particular, the dehumanization of man." ${ }^{119}$ This is all very well, but isn't this more about the motives of contemporary atheists?

Many people are motivated not to subscribe to the belief in an omnipotent, perfectly good, personal god because this would conflict with important values they would prefer to uphold. It is also perfectly possible to say that one can be a "non-believer" in the existence of God (and so an atheist) and a "believer" in human freedom, human dignity, progress, and many other things. As a matter of fact, this is a combination that one often encounters. People's motives for developing an atheist position are often grounded in a laudable type of engagement and not in disillusion. So, in most atheists we find a combination of "belief" and "unbelief," but what they believe in is not God and is sometimes deemed to be irreconcilable with God. That is manifested clearly in a kind of "profession of faith" by the great American infidel Robert Ingersoll (1833-1899). Ingersoll wrote:

I am an unbeliever, and I am a believer .... I do not believe in the "Mosaic" account of creation, or in the flood, or the Tower of Babel, or that General Joshua turned back the sun or stopped the earth. I do not believe in the Jonah story ... and I have my doubts about the broiled quails furnished in the wilderness. Neither do I believe that man is wholly depraved. I have not the least faith in the Eden, snake and apple story. Neither do I believe that God is an eternal jailer; that he is going to be the warden of an everlasting penitentiary in which the most of men are to be eternally tormented. I do not believe that any man can be justly punished or rewarded on account of his belief.

But I do believe in the nobility of human nature; I believe in love and home, and kindness and humanity; I believe in good fellowship and cheerfulness, in making wife and children happy. I believe in good nature, in giving to others all the rights that you claim for yourself. I believe in free thought, in reason, observation and experience. I believe in self-reliance and in expressing your honest thoughts. I have hope for the whole human race. What will happen to one, will, I hope, happen to all, and that, I hope, will be good. Above all, I believe in Liberty. ${ }^{120}$

119 Masterson, Patrick, Atheism and Alienation: A Study of the Philosophical Sources of Contemporary Atheism, Penguin Books, Harmondsworth 1973 (1971), p. 13.

120 Quoted in: Williams, David Allen, A Celebration of Humanism and Freethought, Prometheus Books, Amherst, NY 1995, p. 67. 
Ingersoll was a very successful public speaker, as everyone who reads this passage will understand, and this probably has to do with the fact that he, like no other, understood how to ride the moral high ground. He competed with the religious orators in the sense that he used some of their imagery, e.g. when he writes: "I believe in the religion of reason - the gospel of this world; in the development of the mind, in the accumulation of intellectual wealth, to the end that man may free himself from superstitious fear, to the end that he may take advantage of the forces of nature to feed and clothe the world." 121

It is difficult to cast somebody who writes and speaks like this as a cynic or as someone without firm beliefs and ideals.

As we might expect on the basis of the last sentence from the passage by Ingersoll, one of the most important values that animates much of atheist writing is the attempt to safeguard human freedom. This we encounter in the work of the German philosopher Eduard von Hartmann (1842-1906). In 1874 von Hartmann wrote a small book under the title Die Selbstzersetzung des Christenthums und die Religion der Zukunft [The Self-Annihilation of Christianity and the Religion of the Future]. In that book von Hartmann distinguished between the traditional religious position, based on moral heteronomy, and his own position, which was based on moral autonomy (see Chapter 4). It was the Protestant tradition in Christianity in particular that brought human autonomy to the fore, but, so von Hartmann argued, the principle of moral autonomy, although generated within the Christian worldview, will ultimately destroy Christianity. And he would have been pleased with that. Once one gives primacy to human reason and moral autonomy, the authority of the divine will and scripture have to be rejected: "For the absolute moral principle of Christianity is obedience to the divine will as expressed in Holy Scripture." ${ }^{122}$ This is - and here comes my point - irreconcilable with human freedom, according to von Hartmann. As long as we believe in the theistic god who has created us and the rest of the world we have to conclude that we are nothing, he claims. Our true morality, von Hartmann tells us, can be nothing other than strict submission to

121 See: Ingersoll, R.G., "Why Am I an Agnostic?" North American Review, December 1889, Part I, pp. 1-14, p. 6. See also: Ingersoll, R.G., "Mistakes of Moses," in: R.G. Ingersoll, Complete Lectures of Col. R.G. Ingersoll, M.A. Donogue \& Company, Chicago 1900, pp. 7-19, p. 7: "Now and then someone asks me why I am endeavoring to interfere with the religious faith of others, and why I try to take from the world the consolation naturally arising from a belief in eternal fire. And I answer: I want to do what little I can to make my country truly free. I want to broaden the horizon of our people."

122 Von Hartmann, Eduard, Die Selbstzersetzung des Christenthums und die Religion der Zukunft [The Self-Annihilation of Christianity and the Religion of the Future], Zweite Auflage, Carl Ducker Verlag, Berlin 1874, p. 12. 
the almighty will of this transcendent god. In that situation morality is heteronomous. ${ }^{123}$

True morality, so von Hartmann contended, will always start with human autonomy, and, like Ingersoll, he also spelled out what this implies for the theistic worldview: "then all theistic morality will be necessarily unethical." 124 This implies that the "Christian idea has run its full course." 125 We have to find a new moral perspective for the modern world. As long as we believe in the idea of the theistic God we are nothing but an object, a material object made by a divine creator and, accordingly, limited in our freedom.

A similar argument to von Hartmann's is used by another German philosopher, Nicolai Hartmann (1882-1950). In his Ethics (1926) ${ }^{126}$ Hartmann developed a theory of values that, though objective, have ideal being, affecting the world insofar as men act on them.

It has been rightly said that "the absence of religious thought in Hartmann's philosophy is conspicuous." 127 For the history of atheism Hartmann is important because he denies the existence of a providential God. God's providence would annihilate human freedom. Hartmann, in his "postulatory atheism," teaches the opposite of Kant with regard to God: human freedom does not necessitate us to postulate God, but the reverse. God's nature and human freedom stand in a contradictory relation as "thesis" and "anti-thesis."

\section{Atheist Values}

A similar point was made by the twentieth-century French philosopher Jean-Paul Sartre (1905-1980) in L'existentialisme est un bumanisme [Existentialism is a Humanism] (1946). If we try to imagine a world created by a divine creator, a supernatural craftsman, we, humans, are not free. We can only play the role $\mathrm{He}$ has written for us, and this completely destroys human freedom. So Sartre developed what he called an "atheistic

123 Ibid., p. 30.

124 Ibid.

125 Ibid., p. 91.

126 Reissued in English as: Hartmann, Nicolai, Moral Phenomena, Vol. I of Ethics, With a new introduction by Andreas A.M. Kinneging, Transaction Publishers, New Brunswick, 2002; Hartmann, Nicolai, Moral Values, Vol. II of Ethics, Transaction Publishers, New Brunswick 2003; Hartmann, Nicolai, Moral Freedom, Vol. III of Ethics, Transaction Publishers, New Brunswick 2004.

127 Cerf, Walter, "Nicolai Hartmann," in: Paul Edwards, ed., The Encyclopedia of Philosophy, Vol. III, Macmillan \& The Free Press, New York 1967, pp. 421-426, p. 426. 
existentialism," in contrast with Christian varieties of existentialism that had been developed by Christian philosophers like Gabriel Marcel (18891973). Human freedom demands that we proclaim that man has no "essence," but only "existence." Only within the confines of such an ontology is human freedom secured. ${ }^{128}$

So far we have seen that some thinkers consider that the theistic worldview contradicts human freedom. That has to do with the field of metaethics. But it is also possible to present a critique of the Christian worldview because the values it espouses conflict with our own ethical values. This is the focus of one of the most elegant books on moral and political philosophy from an explicitly atheist point of view: An Atheist's Values (1964) by Richard Robinson. ${ }^{129}$

Robinson (1902-1996) studied philosophy at Oxford and Marburg, taught philosophy at Cornell University for nearly 20 years and then back at Oriel College, Oxford for more than 20 years. ${ }^{130} \mathrm{He}$ wrote on ancient Greek philosophy (in particular Plato and Aristotle) and logic. ${ }^{131}$

What Robinson tried to do in An Atheist's Values is to establish a counterpoint to the "Christian values" that we hear people talk about. He made a distinction between "personal goods" and "political goods." The things that he described as personal goods were beauty, truth, reason, love, conscientiousness, and religion. His treatment of religion was, as one might expect, very critical. Religion is more of an evil than a good because it is gravely inimical to truth and reason. ${ }^{132}$ Faith is a vice. There is no God or afterlife and religion provides no good reason for behaving morally. But Robinson also gave an introduction to political philosophy with his treatment of the "political goods": the state, equality, freedom, tolerance, peace and justice, and democracy.

An Atheist's Values is in many ways a brilliant book, but I fear that its title is somewhat misleading. Many people will be scared off because they expect a long diatribe against religious faith, against Christianity in particular. This is not the case. What Robinson shows is that it is perfectly possible

128 See: Sartre, Jean-Paul, L'être et le néant, Essai d'ontologie phénomenologique [Being and Nothingness, an Essay in Phenomenological Ontology], Gallimard, Paris 1943, pp. 485 ff. and Sartre, Jean-Paul, L'existentialisme est un humanisme [Existentialism Is a Humanism], Les Éditions de Nagel, Paris 1970, p. 17, where he states that all forms of existentialism have in common that "existence precedes essence, or, if you like, that one has to take subjectivity as a point of departure.”

129 Robinson, Richard, An Atheist's Values, The Clarendon Press, Oxford 1964.

130 Walter, Nicolas, "Obituary: Richard Robinson," The Independent, June 14, 1996.

131 See Robinson, Richard, The Province of Logic: An Interpretation of Certain Parts of Cook Wilson's "Statement and Inference," George Routledge, London 1931 and Robinson, Richard, Definition, Oxford University Press, Oxford 1962 (1954).

132 Robinson, An Atheist's Values, p. 113. 
to write about ethics and politics from a purely secular perspective. In other words, a secular life stance is perfectly suited to moral and political reflection.

\section{Spiritual Excellences and the Liberal Decalogue}

Another author who is, in a certain sense, similar to Robinson is L. Susan Stebbing (1885-1943). Stebbing was the first female professor of philosophy in Britain, and what Bill Cooke (1956-) calls a "formidable smiter of humbug." 133 She came down strongly against pretentious woolly thought, as may be gathered from her Thinking to Some Purpose (1939) $)^{134}$ and her Philosophy and the Physicists (1937) ${ }^{135}$ where she targets Sir James Jeans (1877-1946) and Sir Arthur Eddington (1882-1944), two theistic astronomers who, according to Stebbing, strayed from their area of expertise into Christian apologetics.

Stebbing wrote at a time during which British universities were becoming strongholds of analytical philosophy. The attitude of this philosophical movement to values was not altogether appreciative. It associated them with the metaphysical and absolutist philosophy of Plato (c. 428-347 вCE) and his acolytes. So Thomas Dewar Weldon (1896-1958) ${ }^{136}$ wrote somewhat dismissively about

Plato and his modern disciples who suppose that philosophy leads to the discovery of eternal Ideas and Values and that anyone who is acquainted with these must know beyond any possibility of doubt how all States ought to be organized and what the relation of States to one another and to their own members ought to be. This special insight into the nature of reality makes the philosopher the final court of appeal of all kinds of important practical problems such as education, birth-control and the proper use of atomic bombs. ${ }^{137}$

133 Cooke, Bill, Dictionary of Atheism, Skepticism, and Humanism, p. 505.

134 Stebbing, L. Susan, Thinking to Some Purpose, Penguin Books, Harmondsworth 1952 (1939).

135 Stebbing, L. Susan, Philosophy and the Physicists, Dover Books, New York 1958 (1937).

136 Well known for his analytical approach to political philosophy in Weldon, T.D. The

Vocabulary of Politics, Penguin Books, Harmondsworth 1953. The main contribution of this book was, according to Robert Goodin and Phillip Pettit, "to pour cold water on the aspiration of political philosophy to say something important." See: Pettit, Philip, "Analytical Philosophy," in: Robert E. Goodin and Philip Pettit, eds., A Companion to Contemporary Political Philosophy, Blackwell, Oxford 1993, pp. 7-39, p. 9.

137 Weldon, T.D., States and Morals: A Study in Political Values, John Murray, London 1946, preface. 
It is a funny statement, of course, and in the mind's eye the image arises of a pretentious philosopher-cleric who has no practical experience whatsoever and still tries to tell us how "beyond any possibility of doubt" we have to deal with the great political problems of our time. And yet, we may ask ourselves whether a curious and modest philosopher who engages in the analyzing and weighing of values, and subsequently advocates some of these values, necessarily has to cut such a pompous figure. In any case, this is not the impression we get from the work of such intellectually conscientious philosophers as John Stuart Mill, Bertrand Russell, Richard Robinson, and Susan Stebbing. ${ }^{138}$ It seems possible to engage in an analysis of values and still avoid the pretentious claims of the Hegelians that T.D. Weldon and his fellow analytical philosophers revolted against.

Stebbing formulated a different vision from Weldon's. In 1943 she wrote:

Moral philosophers, I contend, must be concerned with the ways in which men live - their ways of life which embody their ideals. I conceive that it falls within the proper province of moral philosophers to formulate ideals worth living for and the attempt to make clear principles which may afford guides for action. This is a task difficult to fulfil. ${ }^{139}$

In Ideals and Illusions (1941) ${ }^{140}$ Stebbing listed "spiritual excellences" that were not based on any religious conviction:

- love for other human beings;

- delight in creative activities of all kinds;

- respect for truth and the satisfaction in learning to know what is true about the world and about ourselves;

- loyalty to other human beings;

- generosity of thought and sympathy with those who suffer, and hatred of cruelty and other evils;

- delight in the beauty of nature and in art; and

- to have experience of pain and of forgoing what would be good for oneself in order that the needs of others may be met. ${ }^{141}$

138 Or a contemporary moral philosopher such as Peter Singer. See, for example: Singer, Peter, Practical Ethics, second edition, Cambridge University Press, Cambridge. 1993 (1979); Singer, Peter, The President of Good and Evil. Taking George W. Bush seriously, Granta Books, London 2004. Both books combine critical acumen with a firm choice of values.

139 Stebbing, L. Susan, “Men and Moral Principles," Oxford University Press, London 1944, also in: Hobhouse Memorial Lectures 1941-1950, Oxford University Press, London 1952, pp. 3-27, p. 4.

${ }_{140}$ Stebbing, L. Susan, Ideals and Illusions, with an introduction by A.E. Heath, Watts \& C., London 1948 (1941).

141 Stebbing, Ideals and Illusions, pp. 29-30. 
Like Robinson, she did not shy away from presenting values, and even wanted to use the word "spiritual" for her "goods" or "values." 142

The last philosopher I want to mention in this context is the most well known, Bertrand Russell (1872-1970). Russell had a tremendous influence on the whole tradition of secularist thought in the twentieth century, of course. To borrow a phrase from Noel Annan (1916-2000), Russell wrote "in a prose whose lucidity was equalled by its elegance." ${ }^{143}$ With books like The Scientific Outlook (1931), Religion and Science (1936), Why I am Not a Christian and Other Essays (1957) $)^{144}$ and many others, he proved to be a paragon of liberal and secular thought in the twentieth century, comparable only with John Stuart Mill in the nineteenth. Russell also wrote an influential history of philosophy, in which his worldview is expressed in sometimes hilarious comments on his fellow philosophers, ancient and modern. ${ }^{145}$ One of his lesser-known pieces, but relevant for our topic, is his "Liberal Decalogue" as part of what he called the "Liberal outlook." $\mathrm{He}$ presented this Liberal Decalogue not as a "substitute" for the Ten Commandments but as a supplement to them. "Perhaps the essence of the Liberal outlook could be summed up in a new Decalogue, not intended to replace the old one but only to supplement it," Russell writes. ${ }^{146}$ But whoever takes cognizance of his "Liberal Decalogue" can hardly fail to notice that it looks more like a devastating criticism of the work of Moses than a "supplement." This is what Russell, as a twentieth-century liberalsecular legislator, presents us with:

1. Do not feel absolutely certain of anything.

2. Do not think it worth while to proceed by concealing evidence, for the evidence is sure to come to light.

142 In her attempt to combine secular ideals with a certain input of spiritualité Stebbing is somewhat similar to the French philosopher André Comte-Sponville whose atheism was characterized by the atheist Michel Onfray as "Christian atheism." Comte-Sponville, André, L'esprit de l'athéisme. Introduction à une spiritualité sans Dieu [The Spirit of Atheism. Introduction to a Godless Spirituality], Albin Michel, Paris 2006.

143 Annan, Noel, Our Age: The Generation that Made Post-War Britain, Fontana, London 1990, p. 101.

144 Russell, Bertrand, The Scientific Outlook, Routledge, London 2001 (1931); Russell, Bertrand, Religion and Science, Oxford University Press, London 1935; Russell, Bertrand, Why I Am Not a Christian: And Other Essays on Religion and Related Subjects, Routledge, London 2004 (1957).

145 Russell, Bertrand, History of Western Philosophy And Its Connection with Political and Social Circumstances from the Earliest Times to the Present Day, George Allen \& Unwin, London 1974 (1946).

146 Under the title "The Best Answer to Fanaticism - Liberalism" published in The New York Times, December 16, 1951, and subsequently included in: Russell, Bertrand, The Autobiography of Bertrand Russell, Unwin Paperbacks, London 1975, pp. 553-554. 
3. Never try to discourage thinking for you are sure to succeed.

4. When you meet opposition, even if it should be from your husband or your children, endeavour to overcome it by argument and not by authority, for a victory dependent upon authority is unreal and illusory.

5. Have no respect for the authority of others, for there are always contrary authorities to be found.

6. Do not use power to suppress opinions you think pernicious, for if you do the opinions will suppress you.

7. Do not fear to be eccentric in opinion, for every opinion now accepted was once eccentric.

8. Find more pleasure in intelligent dissent than in passive agreement, for, if you value intelligence as you should, the former implies deeper agreement than the latter.

9. Be scrupulously truthful, even if the truth is inconvenient, for it is more inconvenient when you try to conceal it.

10. Do not feel envious of the happiness of those who live in a fool's paradise, for only a fool will think that is happiness.

These examples could be augmented ad libitum, but that is not necessary within the confines of this book. My primary purpose is analytical - in particular, to distinguish the concept of atheism (limited or "negative") from the motives that atheists have for subscribing to this position (a predilection for human freedom, as we see in the work of Sartre and von Hartmann, or other specific liberal values, as expounded by Stebbing, Robinson, and Russell).

So, now we have discerned two options. On the one hand we have the theist position, on the other, the atheist perspective. But is the whole spectrum adequately covered by this dichotomy?

\section{Agnosticism}

Many people have the feeling that these two positions do not adequately cover the field. Should we not distinguish a third position, they say, to wit: that we cannot know whether God exists or not? This view is commonly designated as "agnosticism." The agnostic usually claims "to leave open" the question of whether or not God exists. Agnosticism is the theory according to which things within a specified realm cannot be known. ${ }^{147}$ Although that "specified realm" is not necessarily religion, the term is usually applied

147 See: Mautner, Thomas, The Penguin Dictionary of Philosophy, Penguin Books, London 2000 (1996), p. 9. 
in a religious context, more particularly with reference to the existence of God. In that sense the agnostic claims that we cannot know whether or not God exists. ${ }^{148}$ Is this a viable position? Many people are convinced it is. "In all rigour, agnosticism is the only defensible position, and it does not advance anybody one step on the road to atheism or one step on the road to theism," the humanist H.J. Blackham (1903-2009) wrote in 1963.

One of the first questions with regard to the agnostic position is this: what is the agnostic really agnostic about? Does he or she also "leave open" the position that Zeus may exist? Or Allah?

Usually the agnostic does not seriously uphold the idea that the Greek gods may exist. But what exactly is being left unanswered? The agnostic may say: "That's the question, stupid, I do not know. I have no idea about the nature of God, that's exactly the reason why I do not want to affirm or deny his existence." But is that a fruitful position to take? You leave open the existence of something you cannot say anything about.

Probably the agnostic does not leave open the existence of all the gods that humans have venerated from the Stone Age to the twenty-first century, but only the existence of the god that is held in high esteem in the culture in which he or she lives, that is, the theistic god (or God). But in order to leave open the existence of the theistic god, you should at least distinguish some of his characteristics. And once you have done that, why not specify your reasons for holding these characteristics to be compatible or not? Is it impossible to say anything about the likelihood of the existence of a personal, eternal, omnipotent, and perfectly good being? The atheist deems his existence unlikely. The atheist thinks - and here he sides with the theist - that you can argue about those things. The atheist will point out that the existence of evil does not fit in easily with divine omnipotence and perfect goodness. This is adumbrated in a poem by Samuel Porter Putnam (1838-1896).

Putnam was an American atheist and lecturer on freethought whose most important work was a massive history of the freethought movement: Four Hundred Years of Freethought. ${ }^{149}$ Putnam's greatest political success was his effort to defeat a proposal to alter the US Constitution by inserting God into it in 1896. Putnam made a speech before the Joint Judiciary Committee of the US House of Representatives on March 11 and helped to kill the bill. He also wrote poetry. ${ }^{150}$ In "Why Don't He Lend a Hand" from 1890 Putnam presents a mild critique of the idea that God's omnipotence can be reconciled with perfect goodness.

148 Ibid., p. 10.

149 Putnam, Samuel Porter, Four Hundred Years of Freethought, The Truthseeker Company, New York 1894.

150 Cooke, Bill, "Samuel Porter Putnam," in: Tom Flynn, ed., The New Encyclopedia of Unbelief, Prometheus Books, Amherst, NY 2007, pp. 624-625. 
You say there is a God Above the boundless sky, A wise and wondrous deity Whose strength none can defy. You say that he is seated Upon a throne most grand, Millions of angels at his beck Why don't he lend a hand?

See how the earth is groaning, What countless tears are shed, See how the plague stalks forward And brave and sweet lie dead. Homes burn and hearts are breaking, Grim murder stains the land; You say he is omnipotent Why don't he lend a hand?

Behold, injustice conquers; Pain curses every hour; The good and true and beautiful Are trampled like the flower. You say he is our father, That what he wills doth stand; If he is thus almighty Why don't he lend a hand?

What is this monarch doing Upon his golden throne, To right the wrong stupendous, Give joy instead of moan? With his resistless majesty, Each force at his command, Each law his own creation Why don't he lend a hand?

Alas! I fear he's sleeping, Or is himself a dream, A bubble on thought's ocean, Our fancy's fading dream. We look in vain to find him Upon his throne so grand, Then turn your vision earthward -

'Tis we must lend a hand.

'Tis we must grasp the lightning, 
And plough the rugged soil;

'Tis we must beat back suffering,

And plague and murder foil;

'Tis we must build the paradise

And bravely right the wrong;

The god above us faileth,

The god within is strong. ${ }^{151}$

Theodicy, or the reconciliation of evil in the world with God's omnipotence and goodness, has inspired countless debates between theists and atheists. ${ }^{152}$ There is a well-known treatment of this theme in the satirical story, Candide (1759), by Voltaire (1694-1778). Voltaire mocks Leibniz's thesis that it is all for the best in the best of all possible worlds. ${ }^{153}$ James Mill (1773-1836), John Stuart Mill's father, had similar problems with the theistic conception of God. In his Autobiography (1873) John Stuart (1806-1873) wrote about his father: "He found it impossible to believe that a world so full of evil was the work of an Author combining infinite power with perfect goodness and rightness." 154

Richard Robinson (1902-1996) wrote that in the Christian religion, though perhaps not in any other, we frequently find a conception of god that is self-contradictory and therefore corresponds to nothing. That is the conception formed by the following three propositions together:

1. God is all-powerful.

2. God is all-benevolent.

3. There is much misery in the world.

Robinson contended that a god who was all-powerful but left much misery in the world could not be all-benevolent. An all-benevolent god in a world containing much misery would not be all-powerful. A world containing a god who was both all-powerful and all-benevolent would contain no misery. That means that anyone who is confident that he frequently comes across misery in the world may conclude with confidence that there is no such thing as an all-powerful and all-benevolent god. "And this mathematically disposes of official Christianity," Robinson implacably wrote. ${ }^{155}$

151 Quoted in: Stein, Gordon, A Second Anthology of Atheism and Rationalism, Prometheus Books, Buffalo, NY 1987, pp. 180-81.

152 See: Larrimore, Mark, ed., The Problem of Evil: A Reader, Blackwell Publishing, Malden, MA 2008.

153 Voltaire, Candide ou l'Optimisme [Candide or Optimism], Conte philosophique, Éditions Larousse, Paris 2007 (1759).

154 Mill, John Stuart, Autobiography of John Stuart Mill. Published from the original manuscript in the Columbia University Library, with a preface by John Jacob Coss, Columbia University Press, New York 1924 (1873), p. 28.

155 Robinson, An Atheist's Values, p. 124. 
Sometimes apologists of religion respond to this dilemma by declaring the whole affair a "mystery." Or they refer to God's wisdom as being higher than our wisdom. Nevertheless, that would be begging the question. We are still considering whether there is a god, in the sense that he is portrayed in Christian doctrine.

These debates are inconclusive, as so many other philosophical debates are, but they are not meaningless or impossible. Nor are the other discussions of the theistic god. For instance, the question what is the source of morality? Is morality grounded in the will of God? Does the fact that God wills something make that thing eo ipso good? Or is it good in and of itself and therefore willed by God? I will treat some of these problems in Chapter 4 of this book. ${ }^{156}$

These are all important and interesting debates, and the agnostic seems to evade his responsibility as a critical thinker by not participating. By doing this, the agnostic poses as "modest" or "not arrogant," as someone who does not overestimate the capacity of the human mind. But is that pretence justified? Anthony Thiselton (1937- ) writes: “At first sight agnosticism is often perceived as being less dogmatic and more open than either theism or atheism when applied to belief-systems of religions. It appears to suspend the acceptance or rejection of belief." That this pretence is unfounded Thiselton substantiates by referring to the "paradox of skepticism": "How do I know that I cannot know, if I cannot know whether I know?"157

It seems not unreasonable to first ask the agnostic what he understands by "God" before entering into a discussion of whether we can know whether God exists. And one thing is sure. The theistic god as "He" appears to us in the Bible and Qur'an has some definite characteristics we can talk and argue about. If the agnostic does not want to join this debate, fine, but that is more a manifestation of his aversion to the philosophy of religion than an interesting religious or quasi-religious position in itself.

Theists and atheists are discussing the theistic concept of god. They are not discussing some kind of unknowable entity. That implies, of course, that the claims of atheism should be limited, as I have expounded before. George I. Mavrodes seems right when he reminds us: "Atheism is ostensibly the doctrine that there is no God. Some atheists support this claim by arguments. But these arguments are usually directed against the Christian concept of God, and are largely irrelevant to other possible gods. Thus

156 See on this: Rachels, James, “God and Human Attitudes," in: Religious Studies, 7 (1971), pp. 325-37, also in: Rachels, James, Can Ethics Provide Answers? And Other Essays in Moral Philosophy, Rowman \& Littlefield Publishers, Lanham 1997, pp. 109-125.

157 Thiselton, Anthony C., A Concise Encyclopedia of the Philosophy of Religion, Oneworld Publications, Oxford 2002, p. 4. 
much Western atheism may be better understood as the doctrine that the Christian God does not exist." 158

This is partly true. Mavrodes is right that most of the books on the philosophy of religion that have been published in the Western world discuss the characteristics of the theistic God as presented by Christian theologians and philosophers. But because the Christian god is a theistic god and Islam and the Jewish religion subscribe to the theistic concept of god as well, this discussion also has implications for the Islamic and the Jewish concepts of god.

Another question for agnostics is why they do not apply this position to the other dimensions of life. Why be reluctant to choose between the different positions that can be taken with regard to the theistic concept of God and not between those that relate to the other spheres of life? Politics is a difficult business as well. Yet most committed citizens vote. Who has all the available information about politics, international relations, psychology and all the other areas of knowledge where full expertise would be necessary to make a well-considered choice in favor of this government or the other?

\section{The History of Agnosticism}

The intellectual father of agnosticism is the Greek philosopher Protagoras (c. 481-411 BCE), considered to be the "most gifted and original brain among the sophists." ${ }^{159} \mathrm{He}$ is supposed to have written a book "On the Gods" as a result of which he was prosecuted for blasphemy. ${ }^{160}$ Protagoras is well-known for the sentence "man is the measure of all things, of those that are that they are, of those that are not that they are not." ${ }^{161} \mathrm{He}$ regarded all morals and laws as only relatively valid, and binding only in the human community which formulated them. ${ }^{162}$ According to Protagoras there is no absolute religion, no absolute morality, and no absolute justice. His agnosticism appears in his conviction that certain matters are too lofty

158 Mavrodes, George I., "Atheism and Agnosticism," in: Ted Honderich, ed., The Oxford Companion to Philosophy, Oxford University Press, Oxford New York 1995, pp. 63.

159 Zeller, Eduard, Outlines of the History of Greek Philosophy, thirteenth edition, revised by Wilhelm Nestle, Dover Publications, New York 1980 (1883), p. 81.

160 Ibid. Although this may be apocryphal, see: Dillon, John, and Gergel, Tania, eds., The Greek Sophists, Penguin Books, London 2003, p. 2.

161 See: Dillon and Gergel, The Greek Sophists, p. 13.

162 Plato, Theaetetus, 167c, in: Plato, Complete Works, ed. John M. Cooper, Hackett Publishing Company, Indianapolis 1997, p. 186. 
for human beings to form a valid opinion about. ${ }^{163}$ The agnostic attitude is well illustrated by another of Protagoras' sayings:

I am unable to reach knowledge about the gods, either that they exist, or do not exist, or of their essential nature. Among the many factors which prevent me from knowing are the obscurity of the subject and the shortness of human life. ${ }^{164}$

Like agnosticism, atheism was also a well-known position in antiquity. Atheism was associated with Diagoras of Melos. He was surnamed "the godless" and convicted on a charge of impiety. The arguments that Diagoras used are unknown.

Other classical philosophers standing in the agnostic or atheist tradition are Prodicus of Ceos (dates uncertain) and the Athenian Critias (c. 460-403 BCE). In one of his plays Critias made a character argue that the notion of an all-seeing, all-knowing deity was simply a fiction invented by some clever statesman to put the fear of god into wrong-doers. ${ }^{165}$

Because we do not have more than fragments from the pre-Socratic philosophers we can only guess what they thought exactly. Did Protagoras, for instance, referring to the "shortness of human life," think that if human life would have been longer or even infinite we would be able to acquire more knowledge about the gods? If that were the case, this would presuppose that in this life we are able to gather at least some information about the nature of the gods. And if this is possible it might follow that we could bequeath this information to succeeding generations. So why should not our knowledge of the gods grow, just as scientific knowledge grows? Or is the agnostic doomed to be and stay "agnostic"?

Although this remark by Protagoras about the shortness of human life frustrating our knowledge of the gods is intriguing, most self-confessed agnostics seem to consider their agnosticism to be something that is founded in the limited capacity of the human mind. Man is inherently unable to gauge the depth of the divine mind.

The Oxford philosopher Anthony Kenny (1931- ) discusses agnosticism in his autobiography A Life in Oxford. He comments on the work of the poet Arthur Hugh Clough (1819-1861). Clough was an agnostic poet struggling with language to say something about God in his poetry. In a poem from 1851, "Hymnos, Aumnos" (“a hymn, yet not a hymn”), Clough started with the statement that we should search for God in the inner

163 Luce, J.V., An Introduction to Greek Philosophy, Thames and Hudson, London 1992, p. 82.

164 Quoted ibid., p. 82.

165 See: ibid., p. 85. 
dimension of our soul. But we should never presume that we can gauge his qualities.

O thou, in that mysterious shrine

Enthroned, as we must say, divine!

I will not frame one thought of what

Thou mayest either be or not.

I will not prate of "thus" and "so"

And be profane with "yes" and "no."

Enough that in our soul and heart

Thou, whatso'er thou may'st be, art.

This is the agnostic position as formulated by a poet. Kenny, who wrote a monograph on Clough, characterizes agnosticism as follows: "Not only can we not say of God what he is, we are equally impotent to say what he is not." 166

Kenny and Clough fail to notice, however, that presupposed in this question are at least two - highly controversial - characteristics. Apparently God is a "he" (so male) and a "person." But the question arises, what exactly is the difference between agnosticism and atheism for practical purposes? Does the agnostic "sometimes pray," for instance? Just to be sure?

\section{Huxley and Russell}

It was T.H. Huxley (1825-1895) who actually coined the term "agnosticism." He may be familiar to the public at large nowadays as the grandfather of the novelist Aldous Huxley (1894-1963) and the biologist and broadcaster Julian Huxley (1887-1975). “T.H.” was an important character in nineteenth-century Britain, engaged in the struggle for the supremacy of the evolutionist point of view (which brought him the nickname "Darwin's bulldog"). ${ }^{167}$ But a third contribution "T.H." made to Western cultural heritage is less well known. He was the father of "agnosticism."

Huxley coined the concept in 1869 . He used it to designate his own stance toward knowledge of the transcendental realm. Huxley said: "Agnosticism is not a creed but a method." The essence of this method was characterized as follows: it is "the vigorous application of a single principle." This principle has a positive and a negative side. "Positively," Huxley

166 Kenny, Anthony, A Life in Oxford, John Murray, London 1997, p. 230.

167 Desmond, Adrian, Huxley: From Devil's Disciple to Evolution's High Priest, Helix Books, Reading, MA 1994, pp. 195 ff. Karen Armstrong calls Huxley a "crusader." See: Armstrong, Karen, A Short History of Myth, Canongate, Edinburgh 2005, p. 132. 
said, "the principle may be expressed in matters of intellect, follow your reason as far as it can take you without other considerations." And negatively: "do not pretend conclusions are certain that are not demonstrated or demonstrable." 168

Twenty years later he characterized agnosticism in more or less the same way in his essay Agnosticism and Christianity (1889). He wrote: "That it is wrong for a man to say he is certain of the objective truth of a proposition unless he can produce evidence which logically justifies that certainty. This is what agnosticism asserts and, in my opinion, is all that is essential to agnosticism."

As I have said, agnosticism is widely popular nowadays. It can boast great adherence in intellectual circles. About the cause of this popularity one can only speculate. Perhaps agnosticism is considered attractive because it scorns dogmatism. Agnosticism has an air of liberal-mindedness, of tolerance about it.

Agnosticism also exerted a great attraction on one of the most anticlerical minds of the twentieth century, Bertrand Russell. In his long life, which encompassed almost a century (1872-1970), Russell wrote many articles on religious matters. His discussion with Father Copleston (1907-1994), author of a monumental History of Philosophy, on the BBC in 1948 is well known. His essay Why I am not a Christian (1927), published twenty years earlier, also caused much controversy. Russell gained the reputation of a freethinker and an atheist mainly on the basis of these two publications. ${ }^{169}$ But although he wrote disparagingly about God, he did not adopt the term "atheist" to designate his own position. Russell called himself an "agnostic." 170

168 Agnosticism (1869) is included in: Huxley, Thomas Henry, Agnosticism and Christianity and other Essays, Prometheus Books, Buffalo, NY 1992. Commentaries on Huxley in: Pyle, Andrew, ed., Agnosticism. Contemporary Responses to Spencer and Huxley, Thoemmes Press, Bristol 1995. Huxley's Agnosticism is also included in: Stein, Gordon, ed., An Anthology of Atheism and Rationalism, Prometheus Books, Buffalo, NY 1980. On agnosticism see further: Stein, Gordon, “Agnosticism," in: Gordon Stein, ed., The Encyclopedia of Unbelief, Vol. I, Prometheus Books, Buffalo, NY 1985, pp. 3-4 and the excellent introduction by Pyle to the volume mentioned before.

169 See: Copleston, F.C., A History of Philosophy, Vol. VIII, Part II, Image Books Edition, New York 1967, p. 241: "Technically speaking ... he is an agnostic. At the same time he does not believe that there is any real evidence for the existence of God" and Berman, David, $A$ History of Atheism in Britain. From Hobbes to Russell, Routledge, London 1988, p. 230: "For many people Bertrand Russell is the most formidable British atheist, if not the atheist." But, so Berman writes, Russell's criticism on religious matters is not "straightforwardly atheistic.”

170 On the question of what his religion was, Russell answered: "I never know whether I should say "Agnostic" or whether I should say "Atheist." See: Russell, Bertrand, Bertrand Russell on God and Religion, ed. Al Seckel, Prometheus Books, Buffalo, NY 1986, p. 85. 
In 1953 he gave a clear indication of what he thought was the essence of the agnostic position. He responded to the question of whether an agnostic was an atheist, and said: "No. An atheist, like a Christian, holds that we can know whether or not there is a God. The Christian holds that we can know there is a God; the atheist, that we can know there is not. The agnostic suspends judgment, saying that there are not sufficient grounds for affirmation or for denial." 171

From these words it appears that Russell and Huxley were in agreement. Theism and atheism are rejected for the same reasons. Theists and atheists alike pretend to have knowledge about matters one cannot have knowledge of.

It is clear that when two of the most critical minds in the history of freethought - or what is presented here as the secular outlook - prefer the position of the agnostic above that of the atheist, this is cause for serious concern. Agnosticism has always attracted people who scorn the straightforwardness of the atheist position.

Paradoxically, this can again be the basis for a reaffirmation of the theistic position on professed pragmatic grounds. A notorious argument in this direction was presented by the great French seventeenth-century thinker Blaise Pascal.

\section{Pascal's Wager}

Pascal (1623-1662) was many things: a brilliant mathematician, philosopher, and scientist, but also a Christian apologist. Mathematicians recognize him as the inventor of Pascal's Triangle and the calculating machine. Physicists and historians of science acknowledge his pioneering work on the vacuum. In his Provincial Letters (1657) we get to know him as a brilliant theological polemicist. ${ }^{172}$ The word "Jesuitical" owes its pejorative sense to Pascal's satirical attack on the Society of Jesus. ${ }^{173}$ Here I only want to address his ideas on the existence of God. A striking feature of the argument developed in his Pensées [Thoughts] $(1669)^{174}$ is that, just like Huxley and Russell, Pascal denied that we can know for certain whether God exists or not. That does not lead to a position of permanent agnosticism, however, because, he argued, we should bet on God.

171 Ibid., p. 73.

172 Pascal, Blaise, The Provincial Letters, 1657, translated with an introduction by A.J. Krailsheimer, Penguin Books, Harmondsworth 1982 (1967).

173 Hammond, Nicholas, "Introduction," in: Nicholas Hammond, ed., The Cambridge Companion to Pascal, Cambridge University Press, Cambridge 2003, pp. 1-3, p. 1.

174 Published posthumously. See: Pascal, Blaise, Pensées, 1669, translated by A.J. Krailsheimer, Penguin Books, London 1966. 
Pascal's argument is included in almost every anthology of the philosophy of religion. ${ }^{175}$ It is designated as "The Wager."

Somewhat shortened it can be presented thus. According to Pascal, we can never know for certain whether God exists or not.

If there is a God, He is infinitely incomprehensible, since, having neither parts nor limits, He has no affinity to us. We are then incapable of knowing either what $\mathrm{He}$ is or if $\mathrm{He}$ is. This being so, who will dare to undertake decision of the question? Not we, who have no affinity to Him.

So far Pascal seems inclined towards agnosticism, just like Huxley and Russell. But his argument takes a different turn when he introduces the idea that we have to wager. We cannot avoid the choice for or against God. "We are embarked," Pascal wrote. In this situation the choice for God is the most reasonable. Because what do we have to lose and what do we have to gain in making a choice for God? If we gain, we gain all. If we lose, we lose nothing.

Is Pascal convincing? This argument, it would seem, could be contested on several grounds. Many people will retort that we cannot simply start believing - on command - and merely because this will have favorable consequences. Either you believe or you do not. Belief can be compared with love. You cannot love someone because this would have favorable results. Love, like the choice for God, is not possible on the basis of a utilitarian calculus.

Another criticism of Pascal's idea focuses on the moral viability of his pragmatic approach. This matter has also been discussed with regard to the question of whether religious belief is useful for upholding the moral order. We find this in the following contention by Richard Neuhaus (1936-2009): "Religious belief was seen as reinforcement, a backstop, if you will, to the public ethic. Religion, especially in its insistence upon ultimate rewards and punishments, was the motivating force for good behavior." ${ }^{176}$ Shouldn't this be an important argument for accepting religious belief?

This is Richard Robinson's answer to this question. After dissecting the proposition that religion is an important reason for moral behavior, Robinson treats the question of whether religion can be a cause that does in fact makes people obey moral laws. His answer is straightforwardly this:

175 Pascal, "The Wager," in: Louis Pojman, ed., Philosophy of Religion. An Anthology, Wadworth Publishing Company, Belmont, CA 1994, pp. 420-422; Pascal, “The Wager," in: Michael Peterson, et al., ed., Philosophy of Religion. Selected Readings, Oxford University Press, New York 1996, pp. 63-65.

176 Neuhaus, Richard John, The Naked Public Square: Religion and Democracy in America, second edition, William B. Eerdmans, Publishing Company, Grand Rapids, MI 1997 (1984), p. 22. 
The first and most important point to make about this proposition is that, whether it is true or false, to use it as an argument in favor of religious belief is a disgraceful thing to do. To do that is to commit the pragmatic dishonesty of arguing that a creed is true because it is useful that people should believe it. I know that this argument is used extremely frequently, and in the most respected quarters. Nevertheless, it is self evidently null both in logical effectiveness and in common decency. ${ }^{177}$

In short: "To preach a false doctrine, or to preach a doctrine without considering whether it is false or true, is base and beneath human dignity." ${ }^{178}$

But let us leave these moral objections for a moment and concentrate on the question of whether Pascal's argument is convincing purely on a factual basis. According to Pascal, we miss out on something that we would otherwise acquire: eternal happiness. The idea is familiar. He who believes in God (and makes the right choice) will earn heaven. He who does not believe (and makes the wrong choice) will be punished.

Like many modern believers, Pascal did not much emphasize the last aspect. He avoided speaking about the bad news and concentrated on the good news. But it is clear that as important a religious authority as Jesus Christ pointed out the punishments for those who do not believe. Nonbelievers will be thrown "into the furnace of fire" where "men will weep and gnash their teeth," just as "the weeds are gathered and burned with fire" (Matthew 13:40-42). For Ezekiel, the people of Jerusalem had brought their destruction and exile upon themselves by profaning the temple of the Lord, and failing to live up to their obligations as God's people. ${ }^{179}$ Under these circumstances the choice for God seems reasonable.

Yet there is a fundamental flaw in Pascal's Wager that was not very obvious in his time, but invalidates his argument in ours. The problem with Pascal's argument is that he only includes the Christian God in his wager. This may have been comprehensible and excusable in the seventeenth century, but in the twentieth century it is not. We live, in contrast to Pascal, in a religiously pluralistic society. Many gods compete for our attention. We not only have to wager for or against the Christian God, but we have knowledge of the gods of the Greeks, the Romans, the Vikings, the Huns, the Hindus, the Muslims, and all kinds of new gods.

When we further speculate about the character of these gods, we might perhaps presume that the other gods, just like the theist god, are jealous and in a state of competition with their divine rivals.

Under these circumstances betting on one specific god is tricky business. First, we do not have a $50 \%$ chance of making the right choice, but a much

177 Robinson, An Atheist's Values, p. 133.

178 Ibid., p. 134.

179 McGrath, A Brief History of Heaven, p. 45. 
lower percentage. And second, the wrong choice may cause heavy penalties from the gods who are offended by our wrong choice. (Perhaps Pascal currently lives in the hereafter as a Christian Prometheus, being eternally punished by the gods of the Vikings for the wrong choice he made.)

So what would be the most reasonable choice under the circumstance of religious pluralism? It seems to me, the most reasonable choice would be not betting on any god at all. And would that not bring us close to "atheism" in the sense outlined before? That is the concept of "negative atheism" as defended by Ernest Nagel, Charles Bradlaugh, and other authors. The atheist in that sense does not prove that God does not exist but simply does not engage in believing in Him because the evidence is not convincing.

\section{Pascal's Insight}

So far, I have been critical of Pascal's argument as developed in his Wager. I have also dwelled on Pascal's mistake in neglecting the non-Christian religions. But there is something appealing about his approach as well, and this point has great relevance for the viability of agnosticism. The strong point in the argument of Pascal's Wager is that we cannot suspend judgment on the transcendental realm. "Il faut parier" - we have to bet, Pascal wrote. This "we have to" can be seen as an exhortation to bet, but also as the proclamation of the inevitability of a choice.

That last element is the one that is most important to emphasize. As living beings, acting in this world, we all make choices, every day, every moment. We either pray or we do not. We either thank God for our dinner or we do not. We either listen to his moral councils or we do not. We either give sense to life by reference to the religious tradition or we find meaning in life without recourse to the religious dimension. We simply cannot avoid these choices. What we can do, is say that we suspend judgment. But every time that we do not pray, do not give thanks for our dinner, we make a choice. So every human being is a living manifesto of what he or she believes in or not. This is the first dimension of "we have to choose." It is for this reason that I concluded the section on the history of agnosticism with the question: does the agnostic pray sometimes? Choosing is inevitable and is what we actually do.

But Pascal's Wager also (and perhaps mainly) stresses that we should make the choice consciously. Make the leap. Take your stance deliberately. Of course, for Pascal this was an exhortation to make the theistic choice. But what he says about the choice for God and therefore for theism can also be employed for the atheistic choice. Live consciously and rationally "for the unexamined life is not worth living for men," as Socrates told 
us. ${ }^{180}$ Try to give a justification, as well as you can, for the choices you implicitly make, every day, every hour.

This is what both theists and atheists do. Theists try to explain why they believe in God, atheists try to explain why they do not believe in God. Between theism and atheism there is - given the fact that we have to act - no middle ground, at least not an attractive intermediary position, so it seems to me.

The agnostic says he suspends judgment while in every act he chooses in favor of or against God. As Ferdinand Canning Scott Schiller (1864-1937) says: "the emotional value of 'no answer' is equivalent to an answer in the negative." 181 So the agnostic can be adequately defined as the man "who does not know," but his lack of knowledge is not some superior position that goes back to the docta ignorantia of Socrates (470-399 BCE) or Montaigne (1533-1592), but the ignorance of someone who is unable or unwilling to take intellectual responsibility for a philosophical outlook that he honors in his deeds. There surely is some ignorance here. But this is not ignorance of a sophisticated kind, as the agnostic himself considers it to be. This is the ignorance of the unexamined life. As the nineteenth-century lawyer and public intellectual Frederic Harrison (1831-1923) writes in his critique of agnosticism: what the religion of the agnostic comes to is "the belief that there is a sort of something, about which we can know nothing." 182 Agnosticism is not a religion, nor the shadow of a religion; it is "the mere disembodied spirit of dead religion," so Harrison writes in criticizing the work of some nineteenth-century agnostics who wanted to present agnosticism as a remplaçant for traditional religion.

\section{Atheism or Non-Theism?}

In other words, atheism seems to be superior to agnosticism. Does that mean that atheism is the best position? In a certain sense it is. Atheism in the sense defined before is highly defensible. The only problem is, hardly anybody follows the semantic convention that I, following Nagel and others, have proposed. In popular parlance atheism is associated with all kinds of negative ideas and attitudes, especially due to the way it can be defended (and undoubtedly has been defended). Atheists have a reputation

180 Plato, Apology, 38a. Plato, Complete Works, p. 33.

181 Schiller, F.C.S., "Pessimism in Philosophy," in: F.C.S. Schiller, Humanism: Philosophical Essays, second edition, Greenwood Press, Westport, CT 1970 (1912), pp. 157-165, p. 162. 182 Harrison, Frederic, "The Ghost of Religion," The Nineteenth Century, Vol. XV, March 1884, pp. 494-506, also in: Andrew Pyle, ed., Agnosticism: Contemporary Responses to Spencer and Huxley, Thoemmes Press, Bristol 1995, pp. 109-124, p. 111. 
for being arrogant, militant, missionary, zealous, and also impolite if not rude. For that very reason George Jacob Holyoake coined the word "secularism."

George Jacob Holyoake (1817-1906) is most famous nowadays for his trial on the grounds of "blasphemy." 183 During one of his lectures in Cheltenham he was confronted with a question from the audience about man's duty to God. Holyoake's response was that England was too poor to have a God. So it would not be a bad idea to put Him on "half pay." For this remark he was convicted of blasphemy and sentenced to six months in jail. After his release he returned to Cheltenham. There he reiterated the exact words that had gotten him into trouble the first time.

Less well known is the fact that Holyoake coined the word "secularism." He did this because he was convinced that "atheism" was in bad repute. He defined secularism as concern with the problems of this world. He summarized his position in the following words:

(1) Secularism maintains the sufficiency of Secular reason for guidance in human duties. (2) The adequacy of the Utilitarian rule which makes the good of others, the law of duty. (3) That the duty nearest at hand and most reliable in results is the use of material means, tempered by human sympathy for the attainment of social improvement. (4) The sinlessness of well-informed sincerity. (5) That the sign and condition of such sincerity are - Freethought expository speech - the practice of personal conviction within the limits of neither outraging nor harming others. ${ }^{184}$

Holyoake may have been a learned man but he did not possess the gift of making snappy phrases. Nevertheless, in one respect he was right: the concept of "atheism" is hopelessly tainted with negative images, and any author who wants to put this epithet on the banner advertising his lifestyle is confronted with almost insurmountable difficulties. He is constantly obliged to explain his use of the term "atheism" while his audience reacts by saying: "All right, but is not atheism also ...?" And then the whole litany against atheism starts all over again: isn't it a bit arrogant to pretend to know that God does not exist? (Answer: the atheist does not proclaim that God does not exist, he affirms that the reasons to believe in his existence

183 Levy, Leonard W., Blasphemy: Verbal Offense against the Sacred from Moses to Salman Rushdie, The University of North Carolina Press, Chapel Hill 1993, pp. 453-7; Bradlaugh Bonner, Hypatia, Penalties Upon Opinion: Some Records of the Laws of Heresy and Blasphemy, third edition, Watts \& Co., London 1934, pp. 71-75.

184 Holyoake, George Jacob, and Bradlaugh, Charles, "Is Secularism Atheism?” in: Gordon Stein, A Second Anthology of Atheism and Rationalism, Prometheus Books, Buffalo, NY 1987, pp. $345-369$, p. 348. 
are inadequate.) Why are people not allowed to believe in God? (Answer: atheists are not against free speech or against freedom of conscience or freedom of religion; they only claim the right to disagree with anyone who affirms the existence of God.) Isn't atheism a bit arrogant? (Answer: atheism is no more arrogant than agnosticism or theism. The "arrogance" is not in the position itself, but in the way that people hold their opinions: that is, if people are dogmatic or not willing to discuss their views. Atheists are usually fond of discussions. $)^{185}$

That means that although atheism is a defensible position, the odds appear very much against it. This has brought many people to the conclusion that it may be better to keep the position but to change the name. We find this with A.C. Grayling (1949-), for instance. He avoids the term "atheism" when he writes: "I subscribe to a non-religious outlook, and criticize religions both as belief systems and as institutional phenomena which, as the dismal record of history and the present both testify, have done and continue to do much harm to the world, whatever good can be claimed for them besides." 186 So Grayling speaks of a "non-religious outlook." He also writes: "As it happens, no atheist should call himself or herself one. The term already sells a pass to theists, because it invites debate on their ground. A more appropriate term is 'naturalist,' denoting one who takes it that the universe is a natural realm, governed by nature's laws." 187

Another author who avoids the term "atheism" as a designation for his own position is Paul Kurtz (1925- ). Kurtz favors the term "humanism" and speaks of humanism as eupraxophy (good wisdom and practice). By this he means "that humanism expresses a distinctive nonreligious lifestance." 188

Specifically, it advocates a cosmic outlook based upon science and philosophy and a practical ethical approach to the good life. Unlike theoretical science, which seeks to explain how nature operates, or pure philosophy, which is concerned with analysis, eupraxophy attempts to apply knowledge to practical normative issues. I especially wish to contrast humanistic eupraxophy with

185 Although there is a tendency among some liberals not to discuss religion. They mistakenly consider this reluctance to be part of the liberal attitude. See on this: Dacey, Austin, The Secular Conscience: Why Belief Belongs in Public Life, Prometheus Books, Amherst, NY 2008. 186 Grayling, A.C., Against All Gods: Six Polemics on Religion and an Essay on Kindness, Oberon Books, London 2000, p. 9.

187 Ibid., p. 28. See also: Kors, Alan, Atheism in France, 1650-1729, Vol. I, The orthodox sources of disbelief, Princeton University Press, Princeton, NJ 1990, p. 7. Kors writes that Calvin, Luther, Zwingli and also Erasmus were all decried as "atheists" in the debates on their work.

188 Kurtz, Paul, The Courage to Become: The Virtues of Humanism, Praeger, Westport, CT 1997, p. 2. 
both transcendental theistic religion, which often considers the highest moral virtues to be faith, hope, and charity, and the skeptical nihilistic attitude, which denies that there are any objective grounds for the moral virtues. ${ }^{189}$

Holyoake (in countering the atheist Bradlaugh) ${ }^{190}$ seems to be animated by similar concerns. He proposed the term "secularism" as an adequate formula for the convictions outlined above. This is possible, but I will argue that it would be better if the term "secularism" were reserved for the position that I will discuss in Chapter 4 of The Secular Outlook. Perhaps it is better to use the term "non-theism" for the position of a conscious rejection of the thesis that God exists. And if one wants to retain the word "atheism" for its respectable historical lineage it might also be possible to add "private" to the term. In sum, atheism as an integral part of the secular outlook should be "private atheism."

There is some risk involved in using the word "private" in this context, though. Private atheism in the sense expounded above ought not to mean that the atheist should refrain from voicing his or her worldview in a public context. ${ }^{191}$ Nor ought it to mean watering down the claim that the position is better defensible than the theistic one (an atheist is not a relativist). It only means that the atheist should not commit to the view that all people have to subscribe to his or her view of life in order to live peacefully together. Atheists and theists can live together under a constitutional framework that recognizes the "right to read" 192 or freedom of speech and freedom of religion for all the citizens of the state. In that sense there is no need for an atheist to be "missionary" or "militant."

Perhaps the following example can serve as a clarification. A man, let's call him David, does not believe in the existence of God. And not only does David not believe in the existence of God as a kind of gut feeling of the secularized non-reflective individual, but he has read about the topic. He has studied books on the philosophy of religion, has read about the proofs for the existence of God, but, all things considered, he claims to have good reasons not to believe. Nevertheless, he does not make a great point of his unbelief. He specifies the reasons for his unbelief only when his position is challenged. That happens when someone, let's call him Peter, says:

189 Ibid., p. 2. See also: Kurtz, Paul, Eupraxophy: Living without Religion, Prometheus Books, Amherst NY 1998; Kurtz, Paul, Forbidden Fruit: The Ethics of Humanism, Prometheus Books, Amherst NY 1988; Kurtz, Paul, What is Secular Humanism?, Center For Free Inquiry, Prometheus Books, Amherst, NY 2006.

190 Holyoake and Bradlaugh, "Is Secularism Atheism?"

191 This is the trap warned against by Austin Dacey in The Secular Conscience.

192 Blanshard, Paul, The Right to Read: The Battle Against Censorship, The Beacon Press, Boston 1955. 
"What, you are an atheist? How can you find meaning in life?"

"You do not believe in God? How come you behave like a responsible moral agent?"

"No belief in God? How can you raise your children without the idea of an objective moral law?"

David is not only surprised by so much arrogance and lack of knowledge about the topics he has read about but also annoyed. He answers:

"You believe in the existence of a perfectly good, omnipotent and all-seeing God? How can you give meaning to your life if - on the basis of your own suppositions - you are nothing more than an automaton that plays a part in a play predestined by His script? What about human freedom?"

"What? You simply execute the will of God as revealed in His Scripture? So you are going to kill simply because that is written down in an ancient text the origin of which you know hardly anything about?" Or:

"How do you raise your children in a morally justified manner if you do not clearly spell out that the moral law has primacy over all other considerations, religious considerations included? Should you not teach your children that their religious choices have to be made on moral grounds instead of vice versa?"

And let us now ask how David's position should be qualified. Is he an ordinary unbeliever? Not quite perhaps. Is he an atheist? In a certain way he is. One may also qualify him, perhaps, as a "contextual atheist." It is only in certain contexts that he will specify the reasons for his unbelief, for instance in the context of a conversation, as mentioned before. But the most important is that it would be quite unjust if Peter were to react with this: "You're a bit of a dogmatic, stubborn, fundamentalist zealot, aren't you? Member of the Church of Dawkins, are you?" This would be unjust because what David does, is what may be expected from every self-conscious citizen and moral agent. David follows Socrates and reminds us that only the examined life is worth living. He tries to give reasons for his moral choices and he takes his discussion partner seriously. He does not hide behind "personal choices." 193 He does not shy away from addressing the great questions of life. He does not consider it an intrusion of his privacy when asked about his ultimate commitments. On the contrary, as a non-believer he tries to take his believing friends seriously.

It is often said that the debate between theists and atheists is senseless because both positions cannot be proved in any conclusive way. Here is a comment on the debate by the American sociologist Rodney Stark (1934- ), whose thoughts on the secularization thesis I have already discussed in my 
foreword: "It is entirely impossible for science to discover the existence or non-existence of Gods. Therefore, atheistic and theistic assumptions are equally unscientific, and work based on either is equally deficient." 194

This seems to me a not very satisfying approach. It may be true that science cannot establish whether God exists or not. But that does not mean that we cannot sensibly argue about the matter. This is particularly the case when the concept of "god" is sufficiently specific to make a rational debate possible. The theistic god, "God," is sufficiently specific.

Finally we should clearly proclaim that atheism in the sense of private atheism or non-theism does not imply that atheism should be some kind of state doctrine as was the case in the former Soviet Union. So that brings us to three kinds of atheism, or rather three positions an atheist can take towards his own view of life. First, there is "private atheism" or what I will call "non-theism": the view of someone who rejects the theistic worldview and proclaims to do this on good grounds. This is the position of David expounded before. Second, there is "public atheism." Here the atheist creed is perceived to be something that we have to share with fellow citizens, because otherwise no decent society is possible. Here some "missionary" element is involved: the atheist actively wants to "convert" his fellow citizens to his personal conviction. Third, there is "political atheism"; the conviction that the state has to eradicate all kinds of religious belief, as was done in the Soviet Union and in Albania.

Atheism as part of the secular outlook should primarily be private atheism or non-theism: skeptical towards public atheism, and downright dismissive of political atheism. But because using the term "atheism," even in the first sense, has overtones of atheism in the second and third senses it may be advisable to refrain from using the term altogether and rather refer to "non-theism." By doing this, atheists acknowledge that they have won the intellectual battle, but have lost the debate when it comes to public perception.

194 Stark, Rodney, One True God: Historical Consequences of Monotheism, Princeton University Press, Princeton 2001, p. 5. 